\title{
Personel Güçlendirmenin İş Yaşamında Yalnızlık Üzerindeki Etkisinde Kişilik Özelliklerinin Aracılık Rolü
}

\author{
DOI: 10.26466/opus.584629 \\ * \\ $\underline{\text { Emine Sever* }}$ - Mahmut Paksoy** \\ ${ }^{*}$ Doktora Öğrencisi, İstanbul Kültür Üniversitesi, Sosyal Bilimler Enstitüsü / İstanbul / Türkiye \\ E-Posta: eminesever@hotmail.com ORCID: 0000-0001-9760-7447 \\ ** Prof. Dr., İstanbul Kültür Üniversitesi, İktisadi ve İdari Bilimler Fakültesi / İstanbul/ Türkiye \\ E-Posta: m.paksoy@iku.edu.tr \\ ORCID: $\underline{0000-0002-7055-5832}$
}

\section{Öz}

Bu araştırma, personel güçlendirmenin iş yaşamında yalnızlık üzerindeki etkisinde, kişiliközelliklerinin aracıllk rolünü ortaya çıkarmayı hedeflemektedir. Bu amaçla, İstanbul, Hatay, İzmir, Kocaeli ve Zonguldak'da Ana Metal Sanayi, İmalat, Eğitim, Toptan ve Perakende sektörlerinden çalışanlar araştırmaya dâhil edilmiştir. Nicel yöntemlerle elde edilen veriler, SPSS programı kullanılarak bir dizi regresyon analizine tabi tutulmuştur. Analiz sonucuna göre, personel güçlendirme (yaptsal güçlendirme) ile iş yaşamında yalnızlık arasındaki ilişkide, sorumluluk ve duygusal denge kişilik özelliklerinin kısmi ara değişken rolü üstlendiği tespit edilmiştir. Ayrıca, değişkenlerin alt boyutları arasındaki ilişkiler açısından da aracilık rolü incelenmiş ve bu yönde tespitler elde edilmiştir. Dikkat çekici bir bulgu olarak uyumluluk kişilik özelliği, güçlendirmenin "bilgi" boyutu ile yalnızlığın "sosyal arkadaşlık" boyutu arasında tam ara değişken rolü üstlenmiştir. Demografik özelliklerden yaş, kıdem, eğitim, personel statüsü ve sektöre göre, gruplar arasında anlaml farklıllklar olması da önemli bir tespit olarak görülmüştür.

Anahtar Kelimeler: Personel Güçlendirme, Yapısal Güçlendirme, İş Yaşamında Yalnızlık, Kişilik Özellikleri 


\title{
The Mediating Effect of Personality Traits on The Relationship Between Employee Empowerment and Loneliness in The Workplace
}

\begin{abstract}
This research aims to reveal the mediating role of personality traits in the effect of employee empowerment on loneliness in the workplace. Workers from the main metal industry, manufacturing, education, wholesale and retail sectors in Istanbul, Hatay, Izmir, Kocaeli, and Zonguldak were included in the study. The data obtained by quantitative methods were subjected to a series of regression analyzes. According to the results it was found that the dimensions of personality traits named conscientiousness and emotional stability played a partial mediating role in the relationship between structural empowerment and loneliness in the workplace. The mediating role of the dimensions was examined and the determinations in this direction were obtained. As a remarkable finding, agreeableness personality trait plays a full mediating role between the information dimension of empowerment and the social companionship dimension of loneliness. According to age, seniority, education, personnel status and sector, there were significant differences between the groups.
\end{abstract}

Keywords: Employee Empowerment, Structural Empowerment, Loneliness in The Workplace, Personality Traits 


\section{Giriş}

Günümüz iş yaşamında dikey organizasyonların yerini yatay iletişim kanallarına bırakmaya başlaması, çalışanların örgüt içerisinde daha etkin roller almasını, karar alma mekanizmalarına dâhil edilerek katılımlarının sağlanmasını, bilgi kaynaklarına daha kolay ulaşabilmelerini, öz yeterlilik düzeylerini artırmak üzere fırsatlar sunulmasını gerekli hale getirmiştir. Bunun sonucu olarak örgütsel davranış literatüründe güçlendirme, önemli bir çalışma konusu olarak ele alınmaktadır.

Personel güçlendirme kavramı "psikolojik" ve "yapısal" olarak iki temel yaklaşıma dayanmakta olup (Menon, 2001, s.155) bu araştırmada yapisal güçlendirme, inceleme konusuna dâhil edilmiştir. Bunun temel sebebi, yapısal güçlendirmenin örgüt boyutu ile ilgili olması ve örgütün, çalışanın kişiliği üzerinde şekillendirici gücü olabileceği görüşüdür (Arthur vd., 1989, s. 238). Bu kapsamda, yapısal güçlendirmenin kişilik özellikleri üzerindeki etkisini doğrudan inceleyen bir araştırmaya rastlanılamamış olmakla birlikte, çalışanın güçlendirilmesinin onun özyeterlilik bilincini artırdığı bilinmektedir. Bunun da kişilik özelliklerinden "sorumluluk" ile ilgili olduğu düşünüldüğünden Conger ve Kanungo'nun(1988, s.480), güçlendirmenin, bir eylemi başlatma ve devamını getirmek üzere sabır ve azim gösterme gibi belirli kişilik davranışları üzerindeki etkisi araştırılmalı ve test etmeli önerisi dikkate alınmıştır. Bir diğer kişilik özelliği "açıklık" ile ilgili olan inovatif düşünme ve zihinsel merak konusu, Dan ve ark. (2018) tarafından ele alınmış ve yüksek yapısal güçlendirme alg1sının, inovatif düşünceyi artırdığı sonucuna ulaşılmıştır.

Bireyler sahip olduğu kişisel özelliklerini, iş yaşamında karşı karşıya kaldıkları durumlarda sergilemektedir. Böylece, kişilik özelliklerinin iş yaşamında yalnızlık algısı üzerinde önemli bir etkisinin olabileceğini belirtmek mümkündür. Wright (2005), bireysel, örgütsel ve çevresel faktörlerin, kişiler üzerindeki etkisi sonucunda iş yaşamında yalnızlık algısının oluştuğunu belirtmektedir. Yazında, kişilik özellikleri ile iş yaşamında yalnızlık arasındaki ilişkiyi inceleyen birçok araştırma bulunmaktadır (Levin ve Stokes, 1986; Bell vd., 1990; Cheng ve Furnham, 2002; Özçelik ve Barsade, 2011; Zhou, 2018). Bu araştırmaların bulguları incelendiğinde, ki- 
şilik özelliklerinin iş yaşamında yalnızlık üzerinde anlamlı etkisinin, incelenmesi gereken önemli bir konu olduğu tespit edilmiş ve araştırma modelinin kurulmasına katkı sağlamıştır.

Makaledeki hipotezlerin ve modelin oluşturulmasındaki bir diğer önemli husus, yapısal güçlendirme ile iş yaşamında yalnızlık ilişkisi olmuştur. Bu iki değişkeni aynı model üzerinde inceleyen herhangi bir araştırma bulunamamış olmasına rağmen, aralarında bağ kurulabileceğini gösteren çalışmalar literatürde yer almaktadır. Örneğin Kanter'in yaklaşımına göre yapısal güçlendirmenin firsat, bilgi, kaynak, destek, biçimsel ve biçimsel olmayan güç şeklinde altı boyutu bulunmaktadır. Bunu dikkate alarak O'Brain (2010, s.6) yapısal güçlendirmeyi, bu unsurlara ulaşabilme imkânı sunan bir örgüt yeteneği olarak tanımlamaktadır. Lashinger'e göre (2010, s.6), çalışanlar bu unsurlara ulaşamadıkları takdirde kendilerini güçsüz, umutsuz, engellenmiş hissetmektedirler. Bunun getirdiği sonuçlar açısından da devamsızlık, yüksek işten ayrılma niyeti, örgüte bağlılığın ve iş doyumunun azalması gibi olumsuz tutum ve davranışlar oluşmaktadır. İş yaşamında yalnızlık da bünyesinde olumsuz tutum barındıran bir konu başlı̆̆ıdır. Bu bilgilere ek olarak, yapısal güçlendirme ile işten ayrılma niyeti arasında negatif yönlü anlamlı bir ilişkinin (Cai ve Zhou, 2009) ve yine iş yaşamında yalnızlık ile işten ayrılma niyeti arasında pozitif yönlü anlamlı bir ilişkinin (Erdirençelebi ve Ertürk, 2018) tespit edilmesi, bu makaledeki araştırmacıları, yapısal güçlendirme ile iş yaşamında yalnız arasında da anlamlı bir ilişkinin olabileceği varsayıma getirmiştir.

Bu bilgiler ışığında, yapısal güçlendirme ve iş yaşamında yalnızlık arasındaki ilişkinin örgütsel yaşamda önemli bir yer oluşturduğunu belirtmek mümkündür. Bununla birlikte, aralarındaki ilişkinin doğrudan incelenmesi yerine kişilik özellikleri aracılığıyla incelenmesi tercih edilmiştir. Bu üç değişkenin aynı anda ele alındığı bir model bulunamadığı için yazındaki bu boşluğun giderilmesi hedeflenmiş ve bu doğrultuda bir araştırma modeli kurulmuştur. 


\section{Kavramsal Çerçeve}

\section{Personel Güçlendirme}

Personel güçlendirme uygulamaları, pek çok sektör için oldukça önem arz etmektedir. Özellikle ana metal sanayi, emek yoğun çalışma biçimi olan bir sektör olduğundan, çalışanların işleri ile ilgili inisiyatif kullanmaları, ortaya çıkan sorunlara hızlı şekilde çözüm getirme zorunluluğu, "işi en iyi yapan bilir" yaklaşımı bu kavramı vazgeçilmez bir hale getirmektedir. Bunun yanında, çalışanların kendi işleri ile ilgili öneri getirebileceği sistemlerin kurulması, yenilikçi ve yaratıcı bir ortamın oluşturulması, örgütün kârlılığı, verimliliği ve sürdürülebilirliği açısından oldukça önemlidir.

Son yıllarda personel güçlendirme, teorisyenler tarafından organizasyonel etkililiği açıklamak için yoğun olarak kullanılan bir kavram haline gelmiştir. Her geçen gün araştırmacılar ve uygulayıcılar arasında, personel güçlendirme ve bununla ilişkili yönetim pratiklerine, artan bir ilgi söz konusudur. Bunun çeşitli sebepleri bulunmaktadır. Örneğin, liderlik ve yönetim becerileri üzerine yapılan çalışmalarda personel güçlendirme uygulamalarının, yönetimsel ve organizasyonel etkililik için, çok önemli bir bileşen olduğunun gösterilmesidir. Bir başka sebep, organizasyonlar içerisindeki güç ve kontrolün irdelenerek, üstlerin bu güç ve kontrolü astları ile paylaşması neticesinde, daha etkili ve verimli iş modellerinin ortaya çıkmasıdır. (Conger ve Kanungo, 1988).

Thomas ve Velthouse (1990)'a göre güçlendirme, gücü başkalarına vermektir. Güç ise otorite, kapasite ve enerji demektir. Bunun sonucunda güçlendirme kavramı, yetkilendirme, öz yeterlilik ve enerjik hale getirme olarak tanımlanabilir. Enerjik hale getirmek, bu kavramın motivasyonel kullanımını yansıtmaktadır. Kanter'e göre (1979), liderlerin kendi güçlerini, çeşitli araç ve bilgiler ile destekleyerek çalışanları ile paylaşmaları, personel güçlendirme olarak ifade edilir.

Güçlendirme kavramı temel olarak, çalışanların yapmış oldukları işlerle ilgili, yöneticilerinin onayına gerek duymadan karar alabilme ve inisiyatif kullanabilme yetkisinin verilmesi olarak tanımlanabilir. Bunun sonucu olarak, çalışanlar kendi alanlarındaki sorunlarla doğrudan ilgilenme, onlarla ilgili çözüm üretme, kararlar alma ve o kararları uygulama 
konularında yetkilerini kullanırlar, sorumluluğunu da taşırlar (Barutçugil, 2004).

Bowen ve Lowler ise personel güçlendirmeyi, çalışanlar ile dört organizasyonel içeriğin paylaşılması olarak tanımlar (Bowen ve Lawler, 1992). Bunlar, 1-organizasyonun performansı ile ilgili bilgi paylaşımı, 2-organizasyonun performansına dayalı olarak ödüllerin paylaşımı, 3-çalışanların organizasyonun performansını anlamalarına ve buna katkı sağlamalarına yönelik bilgilerin paylaşımı, 4-organizasyonun yönünü ve performansını etkileyecek karar alma gücünün paylaşımıdır. Bir sonraki bölümde, Personel güçlendirmenin "psikolojik" ve "yapısal" olarak dayandığı iki temel yaklaşımdan, araştırma modeli açısından Yapısal Güçlendirme boyutu ele alınmıştır.

\section{Yapısal Güçlendirme}

Personel güçlendirme ile ilgili pek çok araştırmacı farklı yaklaşımlar ve sınıflandırmalar kullanmıştır. Bunlardan en yaygın olanları, yönetsel uygulamalar, yöneticinin rolü, ödül sistemleri, bilgi kaynakları gibi araçlarla "yapısal güçlendirme" kavramını açıklayanlar (Honold, 1997) ve güçlendirme için yapılması gereken faaliyetlerden daha çok bunların çalışanlar tarafından nasıl algılandığı, iç motivasyonları ile ilgili "psikolojik güçlendirme" kavramını açıklayanlardır (Thomas ve Velthouse, 1990).

$\mathrm{Bu}$ çalışmanın dayandığı kuramsal çerçeve, Laschinger'in "Yapısal Güçlendirme Yaklaşımı"ndan oluşmaktadır. Laschinger yapısal güçlendirme yaklaşımının kuramsal alt yapısını, Kanter'in yapısal güçlendirme yaklaşımından almaktadır. Kanter(1977), "Men andWomen of the Corporation" adlı kitabında, bireylerin amaçlarına ulaşmaları için mevcut kaynaklardan yararlanmaları ve özgür biçimde karar alabilme yeteneklerini, güçlendirme olarak tanımlamıştır (Tolay vd., 2012, s.451).

Kanter'in(1993) organizasyonlardaki yapısal güçlendirme yaklaşımı, organizasyonların çalışanlarına başarılı olma fırsatı sağlamaları, onları güçlendirmek için fırsat yapısı ve güç yapısı sunmaları gerektiğini iddia eder. Fırsat yapısı, çalışanların bilgi ve becerilerini geliştiren, onların örgüt içerisinde ilerleme olanaklarını sağlayan, iş koşulları ile ilgilidir. Bu şekilde çalışanlar, değişim ve yeniliklere ayak uydurmak, iş yerinde ortaya 
çıkan problemleri çözmek üzere proaktif bir yaklaşım sergileme olanaklarına sahip olurlar. Güç yapısı ise, çalışanları etkin bir şekle getiren bilgi, destek ve kaynak sağlayan örgütsel özellikler olarak tanımlanır. Kanter'e göre bu güçlendirme yapılarına erişmek, biçimsel ve biçimsel olmayan güç sistemleri aracılığı ile daha kolay bir şekilde olabilir (Laschinger vd., 2010, s.5).

\section{Yapısal Güçlendirmenin Boyutları}

Yapısal güçlendirmenin fırsat, bilgi, destek, kaynak, biçimsel güç ve biçimsel olmayan güç şeklinde alt boyutları bulunmaktadır. Fırsat, çalışanların örgüt içerisinde bilgi ve becerilerini geliştirme, onların ilerlemelerine olanak sağlanmasıdır. Bilgi, çalışanların işlerini anlamlı bir şekilde yerine getirebilmeleri için gerekli olan bilginin sağlanmasıdır. Destek, çalışanların, yöneticilerinden, iş arkadaşlarından ve astlarından performansları ile ilgili geri bildirim almaları, etkili bir şekilde yönlendirilmeleri ve gerektiği durumlarda yardım edilmesidir. Kaynak, çalışanların işlerini daha etkili şekilde yapabilmeleri için gerekli olan bütçe, zaman, insan ve malzeme kaynaklarının sağlanmasıdır. Biçimsel Güç, çalışanların yapmış oldukları işlerin, örgüt içerisinde görünürlüğünün sağlanması, işleri ile ilgili esneklik imkânının olması ve işlerine kattıkları yenilikler sonucunda ödül ve teşviklerin verilmesidir. Biçimsel Olmayan Güç, çalışanların kendilerini geliştirebilecekleri eğitim kurumları ile iş birliği yapabilme imkânlarının, mevcut sorunlara yöneticileri ve çalışma arkadaşları ile birlikte ortak çözüm yolları bulmalarının sağlanmasıdır (Laschinger ve Heather, 2012).

\section{Yalnızlık}

Günümüzde bireyleri etkileyen bir diğer önemli konu yalnızlık kavramıdır. Yalnızlık, çağdaş iş yaşamında bireylerin içerisinde var olan yaygın bir duygusal durumdur. Çeşitli araştırmacılar yalnızlık kavramını farklı tanımlamalarla ele almaktadır. Perlman ve Peplau'ya göre (1984) yalnızlık, kişilerin sosyal ilişkilerinde hem nitelik hem de nicelik açısından anlamlı bir eksikliğin oluşması durumunda ortaya çıkan, arzu edilmeyen bir durumdur. Bu tanımlama, yalnızlık konusunu ele alan diğer pek çok araş- 
tırmacının da uzlaştığı üç görüşü içermektedir. Birincisi, yalnızlık, bir insanın sosyal ilişkilerindeki eksikliğin bir sonucudur. Yalnızlık, bir insanın mevcut sosyal ilişkileri ile ihtiyaç duyduğu ve arzu ettiği sosyal iletişimleri arasında bir uyumsuzluk olduğunda ortaya çıkar. İkincisi, yalnızlık öznel bir deneyim olup toplumsal yalnızlıkla aynı anlama gelmemektedir. Kişiler kalabalık içerisinde de yalnızlık duygusu yaşayabilirler. Üçüncüsü ise, yalnızlığın istenmeyen ve üzüntü verici bir durum olduğudur.

Andersson(1993) yalnızlığın depresyon, anksiyete, yorgunluk, sırt ağrısı, baş ağrısı, baş dönmesi, çarpıntı, nefes darlığı, psikosomatik şikâyetler, nevrotiklik gibi bir dizi olumsuz faktörle ilişkili olduğundan bahsetmektedir. Ponzetti'ye göre (1990) ise yalnızlık, kişiler için arzu edilmeyen, rahatsızlık veren, endişeyle bakılan çok yönlü bir olgudur.

Yalnızlık kavramını genel olarak ele aldıktan sonra, araştırmaya konu olan iş yaşamında yalnızlık aşağıda açıklanmıştır.

\section{İş Yaşamında Yalnızlık}

İş yaşamında yalnızlık konusu, örgütlerde giderek daha fazla önem kazanmaktadır. Bunun sonucu olarak da düşük iş performansı, iş bırakma eğilimi ve iş tatmini gibi üzerlerinde olumsuz etki yaptı̆̆ konuların incelendiği çok sayıda araştırma bulunmaktadır (Aytaç ve Başol, 2018; Ertosuna ve Erdil, 2012; Özçelik ve Barsade, 2011).

İş yaşamında yalnızlık, arzu edilen kaliteli ilişkiye ulaşma isteğinden kaynaklanmaktadır. O açıdan bir kişinin iş yerindeki memnuniyetsizliği, o iş yerinde iletişim kurmuş olduğu kişilerin nicelik olarak azlığından değil, ilişkilerin arzu edildiği kalitede kurulamayışının verdiği yalnızlık duygusundandır (Wright vd., 2006). Bir başka ifade ile iş yaşamında ortaya çıkan yalnızlık, genel yalnızlık kavramından farklı olarak yalnızca iş yerinde etkin olabilmektedir. Günlük yaşamında oldukça tatmin edici ve sağlıklı ilişkileri olan ve yalnızlık duygusu yaşamayan bir kişi, iş yaşamında arzu edilen sosyal ilişkiler kurmakta ve sosyal destek almakda zorluklar yaşayabilmektedir. Bunun sonucu olarak, bireyin iş yaşamında yalnızlık ve dışlanmışlık duyguları yaşamasına neden olabilmektedir (Doğan vd., 2009). 


\section{1. İş̧ Yaşamında Yalnızlı̆̆ın Boyutları}

Weiss(1973) yalnızlığı, duygusal ve sosyal yalnızlık olarak iki boyutta ele almıştır. Duygusal yalnızlık, bireylerin diğerleri ile yakın ilişkiler kurduğu durumlarda ortaya çıkan duygularla ilgilidir. Kişi duygusal olarak yalnız hissettiğinde, üzüntülü olma ve boşluk hissine kapılma eğiliminde olup diğer bireylerle yakın ilişkiler kurma arzusu içerisindedir. Sosyal yalnızlık ise arkadaş gruplarındaki ilişkilerde olduğu gibi, bireylerin grup içerisindeki ilişkilerinde yaşadığı duygularla ilgilidir. Sosyal yalnızlık içerisinde olan bireyler, gerçekten grubun bir parçası olup olmadıklarına şüphe ile yaklaşırlar (Wright, 2005).

\section{Kişilik}

Fiziksel özelliklerin aksine, kişilik özellikleri doğrudan ölçülemeyen ve bundan dolayı gözlemlenebilen ve gözlemlenemeyen davranış kalıplarından çıkarımların yapılabileceği soyut bir kavramdır. Kişilik üzerine çalışan uzmanların bu çıkarımları yapabilmesi için, gözlem formlarına veya anket ifadelerine verilen cevaplara ihtiyaçları vardır (McCrae ve Costa, 1997, s.510).

Aytaç'a göre (2007) kişilik, bireyleri birbirinden ayıran veya onların diğerlerinden farklılaşmasını sağlayan en önemli faktördür. İnsan doğasını anlamanın zorluğunun yanında, düşünce, davranış ve tutumlar da insandan insana, toplumdan topluma ayrışmaktadır. Bu durum da her bir insanı özgün ve diğer bireylerden farklı yapmaktadır. İnsana bu bireyselliği kazandıran özellikler "kişilik" denilen, onun kendisi ve çevresiyle, başkalarına benzemeyen kendine özgü geliştirdiği ilişkilerin yapısıdır.

\section{Kişilik Özellikleri ve Boyutlan}

Kişiliği açıklama konusunda literatürde pek çok yaklaşım bulunmakla birlikte, kişisel farklılıkları dikkate alan ve gözlemlenebilen davranış biçimlerinden hareket eden "özellik yaklaşımı" ön plana çıkmaktadır. Bu yaklaşım, bireylerin kendilerini ve diğerlerini tanımlamada kullandıkları sözcüklerin analizinden hareket etmesi, olaylar karşısında sergiledikleri 
davranışların tutarlı olması ve bu davranışların kalıtımsal özellik taşımasıyla ön plana çıkmaktadır (McCrae vd., 2001).

Özellikler Kuramı ile kişilik özelliklerini belirlemeye yönelik ilk çalışma 1936 yılında Allport ve Odbert tarafından yapılmıştır. RaymondCattel(1946), bu çalışmadan yola çıkarak davranış modellerini üç gruba ayırmıştır. Birincisi yaradılış, duyarlılık, nevrotik belirtiler, baskınlık gibi hareketli özellikler, ikicisi duygusallık, vazgeçmeme, kişisel tarz, inatçılık gibi mizaç özellikleri, üçüncüsü ise zekâ, zamanla oluşan algılar ve yönetim becerileri gibi yetenek ve bilişsel özelliklerdir. Bu özellik yaklaşımı, Beş Büyük Kişilik Kuramı'nın temelini oluşturmuştur.

Bu yapının isimlendirilmesi hususunda fikir ayrılıkları olsa da yapılan pek çok çalışma, bu yapının kişilerarası farklılıkları ortaya çıkarma anlamında genel olarak kabul gördügüüü göstermektedir. Bu kişilik yapısı "Dışadönüklük" (Extraversion), "Duygusal Denge" (Neuroticism), "Uyumluluk" (Agreeableness), "Sorumluluk" (Conscientiousness) ve "Açıklık" (Openness) boyutlarını içermektedir. Dışadönüklük boyutunu tanımlayan sıfatlar, girişken, aktif, konuşkan, iddialı, maceracı, heyecan odaklı, iyimser ve sıcakkanlı şeklindedir. Duygusal denge boyutunu tanımlayan sıfatlar, endişeli, kaygıll, depresif, güvenmeyen, benlik bilinci olmayan ve k1rılgan şeklindedir. Uyumluluk boyutunu tanımlayan sıfatlar, dürüstlük, uyma, alçakgönüllülük, güven ve merhamet şeklindedir. Sorumluluk boyutunu tanımlayan sıfatlar, dikkatli, kararlı, başladığı işi bitiren, sabırlı, azimli, hurslı, başarma yönelimli, sistemli ve titiz şeklindedir. Açıklık boyutunu tanımlayan sıfatlar, analitik, geleneksel olmayan, bağımsız, meraklı, liberal, özgün, hayal gücü kuvvetli, yaratıcı, ilgi alanları geniş ve değişikliği seven şeklindedir (Costa vd., 1986, s.641).

\section{Personel Güçlendirme, İş Yaşamında Yalnızlık Ve Kişilik Özellikleri Ara- sındaki İlişkiler Üzerine Yapılan Araştırmalar}

Literatür taraması sonucunda, yapısal güçlendirme, iş yaşamında yalnızlık ve kişilik özellikleri arasındaki ilişkilerin aynı anda incelendiği bir araştırmaya rastlanılamamıştır. Bu açıdan, her bir değişkenle ilgili farklı araştırmalar ve kişilik özelliklerinin aracılık rolünü ele alan çalışmaların sonuçları üzerinde durulmuştur. 
Sanayi sektöründe personel güçlendirme ile ilgili araştırmalardan birisi, İran'ın Markazi bölgesindeki özel sektör ve kamu kurumlarına ait 40 sanayi kuruluşunda çalışan 50'nin üzerinde kişiye uygulanmıştır. Bu araştırmanın sonucuna göre, Markazi bölgesindeki imalat şirketlerinde, personel güçlendirme ile bireysel, örgütsel, yönetimsel ve çevresel faktörlerle arasında, nispeten güçlü bir ilişki olduğu sonucuna varılmıştır (Fatahi vd., 2016, s. 102). Bir başka araştırma, Çin'de 460 hemşire üzerinde Dan ve arkadaşları (2018) tarafından yapılarak, yapısal güçlendirmenin, inovatif davranış, özyeterlilik ve kariyer başarısını artırdığı bulgusu elde edilmiştir. Barselona' da bir sağlık merkezinde 131 hemşire üzerinde yapılan araştırmada ise, yapısal güçlendirme aracılık rolü açısından ele alınmış ve dönüşümcü liderlik ile bağlılık arasında pozitif bir etkisi olduğu bulunmuştur. Taş işleme sektöründe çalışan 112 kişi üzerinde yapılan araştırmada, yapısal güçlendirmenin örgütsel vatandaşlık davranışı üzerinde pozitif yönlü ve anlamlı bir ilişkisi saptanmıştır (Yasım ve Işık, 2017).

Yapılan araştırmalar incelendiğinde iş yaşamında yalnızlığın öncüllerine ilişkin kısıtlı sayıda araştırmaya ulaşılmıştır. Bu kapsamda, aşırı iş yükü ile işten ayrılma niyeti arasındaki ilişkide iş yaşamında yalnızlığın aracılık rolü üzerine 145 kamu çalışanı ile yapılan bir araştırmada, iş yaşamında yalnızlık tam ara değişken olarak tespit edilmiştir (Aytaç ve Başol, 2018). Yazında, sosyal desteğin yalnızlık ile negatif yönlü bir ilişkisinin olduğunu gösteren ve 52 üniversite öğrenci üzerinde yapılan bir araştırma yer almaktadır (Rhodes, 2014).

Kişilik özellikleri ile iş yaşamında yalnızlığın bir arada ele alındığı araştırmalar da bulunmaktadır. Bunlardan bir tanesi, yaşları 16 ile 18 arasında değişen 90 ergenin kişilik özelliklerinin, yalnızlık algılarını negatif yönde anlamlı şekilde etkilediği yönündedir (Cheng ve Furnham, 2002). Bir diğeri ise, 124 üniversite öğrencisinin kişilik özellikleri ile yalnızlık algıları arasındaki ilişkiye yönelik olup, kişilik özellikler ile yalnızlık arasında anlamlı farklılıklar olduğu saptanmıştır (Levin ve Stokes, 1986). Ayrıca, iş yaşamında yalnızlı̆̆ yordamada kişilik özelliklerinin rolünü incelemek üzere 201 akademik personelden veri elde edilmiş ve sorumluluk dışında kalan diğer tüm kişilik özelliklerinin, anlamlı şekilde farklılaştığı tespit edilmiştir (Çetin ve Alacalar, 2016). 


\section{Yöntem}

\section{Araștırmanın Önemi ve Amacı}

Literatürde yapısal güçlendirme, iş yaşamında yalnızlık ve kişilik özellikleri ile ilgili pek çok çalışma bulunmakla birlikte, bu değişkenlerin aynı model içerisinde incelenmesine yönelik bir araştırmaya pek rastlanılamamıştır. Bundan dolayı bu araştırma, özgün bir çalışmadır. Verilerin farklı şehir ve sektörlerden elde edilmesi, personel statüsü açısından beyaz yakalı ve mavi yakalı çalışanların bulunması, demografik özellikler açısından da konunun ele alınmış olması çalışmanın önemini daha da artırmaktadır.

\section{Araştırmanın Kapsamı}

Araştırmanın evrenini İstanbul, Hatay, İzmir, Kocaeli ve Zonguldak illerindeki Ana Metal Sanayi, İmalat, Eğitim, Toptan ve Perakende gibi farklı sektörlere ait kurumsal firmalarda çalışan beyaz ve mavi yakalı çalışanlar oluşturmaktadır. Anket verileri, tesadüfî olmayan kolayda örnekleme yöntemi kullanılarak 280 kişiye elektronik ortamda veya elden dağıtılmış, 181 'inden geri dönüş sağlanmıştır. Fakat 4 anket formundaki bilgiler eksik olduğu için değerlendirme dışında bırakılmış ve örneklem sayısı 177 olarak belirlenmiştir.

\section{Araştırmaya Katılanların Demografik Özellikleri}

Demografik özellikleri incelendiğinde 95'i kadın (\%54), 82'si erkek (\%46) olan katılımcıların yaşları 20 ile 59 arasındadır $(\overline{\mathrm{X}}=37,8)$. Medeni durumları açısından ağırlıklı olarak (\%63) evli, \%37'si ise bekâr olduğunu belirtmiştir. Eğitim seviyeleri dikkate alındığında çoğunluğu (\%59) lisans, yüksek lisans ve doktoralıdır. Mavi yakalı 62 (\%35) çalışan, beyaz yakalı ise 115 (\%65) çalışan bulunmaktadır. Kıdemleri 1 ile 37 yıl arasında değiş̧mekte $(\overline{\mathrm{X}}=7,6)$ ve \%56'sının 0-5 yıl aralığında olduğu görülmektedir. Katılımcıların \%28'si Ana Metal Sanayi, \%13'ü Eğitim, \%40'1 İmalat, \%19'u Toptan ve Perakende Ticaret sektöründe olduğunu ifade etmiştir. Yönetici pozisyonunda ise $\% 34$ '̈u yer almaktadır. 


\section{Araştırma Modeli, Değişkenleri ve Hipotezleri}

Çalışmada, araştırmaya katılanların yapısal güçlendirmeye ilişkin algılarının onların kişilik özelliklerini değiştirebileceği ve böylece iş yaşamında yalnızlık algılarını etkileyeceği varsayımına dayanarak bir model geliştirilmiştir (Bknz: Şekil 1). Modele göre yapısal güçlendirme "bağımsız değişkeni", iş yaşamında yalnızlık da "bağımlı değişkeni" oluşturmaktadır. Ayrıca, kişilik özellikleri (dışadönüklük, duygusal denge, açıklık, uyumluluk, sorumluluk), yapısal güçlendirme ile iş yaşamında yalnızlık arasında "aracı (mediator) değişken" olarak ele alınmaktadır. Araştırma modelinden yola çıkarak oluşturulan hipotezler aşağıdaki gibidir:

- H1: Personel güçlendirmenin iş yaşamında yalnızlık üzerindeki etkisinde kişilik özelliklerinin aracılık rolü vardır.

- H1a: Yapısal güçlendirmenin iş yaşamında yalnızlık üzerindeki etkisinde, açılık alt boyutunun aracılık rolü vardır.

- H1b: Yapısal güçlendirmenin iş yaşamında yalnızlık üzerindeki etkisinde, sorumluluk alt boyutunun aracılık rolü vardır.

- H1c: Yapısal güçlendirmenin iş yaşamında yalnızlık üzerindeki etkisinde, dişadönüklük alt boyutunun aracılık rolü vardır.

- H1d: Yapısal güçlendirmenin iş yaşamında yalnızlık üzerindeki etkisinde, duygusal denge alt boyutunun aracılık rolü vardır.

- H1e: Yapısal güçlendirmenin iş yaşamında yalnızlık üzerindeki etkisinde, uyumluluk alt boyutunun aracılık rolü vardır.

- H2: Değişkenlerin her biri, demografik özelliklere göre farklılık göstermektedir.

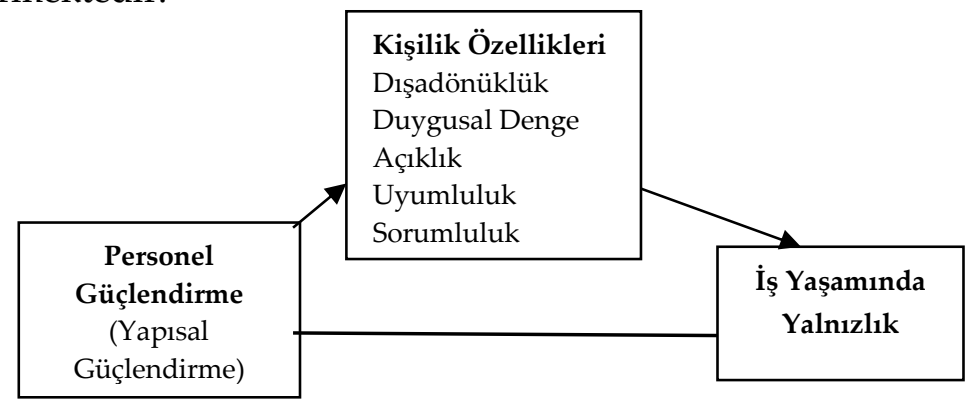

Şekil 1: Araştırma Modeli 


\section{Ölçme Araçları}

1. Yapısal Güçlendirme Ölçeği: (Conditions of WorkEffectivenessQuestionnaire-II CWEQ): Yapısal güçlendirme ölçeğinin fırsat, bilgi, destek, kaynak, biçimsel güç ve biçimsel olmayan güç başlıklı 6 alt boyutu bulunmaktadır ve 5'li Likert Ölçeği ile derecelendirilmiştir. Buna göre, katılımcılardan soru formunda verilen ifadeleri, mevcut işlerinde ne düzeyde yaşadıklarını, 1'den (Hiç), 5’e (Çok) uzanan 5'li ölçek üzerinde işaretlemeleri istenmiştir. Ölçekten alınan yüksek puanlar, yüksek güçlendirme algısına işaret etmektedir (Laschinger ve Heather, 2012). Ölçeğin çevirisi Ton (2008) tarafından yapılmıştır. Bu araştırmada kullanılan ölçeğin geçerliliği ise Tolay, Sürgevil ve Topoyan(2012) tarafından yapılan "Akademik Çalışma Ortamında Yapısal ve Psikolojik Güçlendirmenin Duygusal Bağlllık ve İş Doyumu Üzerindeki Etkileri" çalışmasında yapılmıştır.

2. İş Yaşamında Yalnızlık Ölçeği: Loneliness at WorkScale (LAWS): İş Yaşamında Yalnızlık Ölçeği, Wright, Burt ve Strongman(2006) tarafından geliştirilmiştir. Ölçek toplam 16 sorudan ve “Duygusal Yoksunluk ile "Sosyal Arkadaşlık" olmak üzere iki alt boyuttan oluşmaktadır. Ölçeğin Türkçe formunun geçerlilik ve güvenirlilik çalışması Doğan ve arkadaşları tarafından yapılmıştır (Doğan vd., 2009).

3. Beş Faktör Kişilik Ölçeği (BFI): Beş faktör kişilik özelliklerini ölçmek için 44 ifadeden oluşan, John, Naumann ve Soto(2008) tarafından geliştirilen Beş Büyük Kişilik Ölçeği (BFI) kullanılmıştır. Beş Büyük kişilik özelliği ölçeği dişadönüklük (8 ifade), duygusal denge (8 ifade), uyumluluk (9 ifade), sorumluluk (9 ifade) ve açıklı (10 ifade) olmak üzere beş boyuttan oluşmaktadır. Ölçekte ters ifadeler yer alıp, bu ters ifadelerle ilgili değerler kodlanırken ters puanlama yapılmıştır. Ölçeğin Türkçe'ye uyarlamasında Süren'in(2015) çalışmasından yararlanılmıştır.

\section{Araştırmada Kullanılan Ölçeklerin Güvenilirlik ve Geçerlilik Analizleri}

Ölçeklerin iç tutarlılıkları Cronbach Alpha güvenirlik analiziyle test edilmiştir. Ölçeklerin alt boyutları için faktör analizine başvurularak, Temel 
Bileşenler (principlecomponents) yöntemi ve Varimax döndürme (rotation) metodu kullanılmıştır. Örneklemin yeterlilik düzeyi ve faktör analizine uygun olup olmadığ $\breve{1}$ ise Kaiser-Meyer-Olkin (KMO) ve Bartlett küresellik testleriyle değerlendirilmiştir. Her bir hipotez testi için regresyon analizi yapılmıştır.

\section{1. Ölçeklerin Güvenilirlik Analizleri}

Güvenilirlik analizi, daha önceden belirlenmiş bir ölçek türüne göre hazırlanmış ankete verilen yanıtların tutarlılığını ölçer. Güvenilirlik analizi için kullanılan temel analiz Cronbach's Alpha $(\alpha)$ değerinin bulunmasıdır. Tüm sorular için elde edilen $\alpha$ değeri o anketin toplam güvenilirliğini gösterir ve $0,7^{\prime}$ den büyük olması beklenir, bu değerden düşük $\alpha$ değerleri anketin zayıf güvenilirliği olduğunu gösterir, $\alpha>0,8$ olması ise anketin yüksek güvenilirliğe sahip olduğunu göstermektedir (Can, 2017). Bu araştırmada kullanılan ölçeklerin güvenilirlik analizleri Tablo 1'de listelenmiştir.

Tablo 1. Ölçeklerin Güvenilirlik Analizi

\begin{tabular}{ll}
\hline Ölçek & Cronbach's Alpha \\
\hline Yapısal Güçlendirme Ölçeği & 0,944 \\
\hline İş Yaşamında Yalnızlı Ölçeği & 0,917 \\
\hline Beş Faktör Kişilik Ölçeği & 0,713 \\
\hline
\end{tabular}

\section{2. Ölçeklerin Geçerlilik ve Faktör Analizleri}

Araştırmanın yapısal geçerliliğini analiz etmek üzere faktör analizi kullanılmıştır. Yapısal geçerliliğin tahmini sırasında faktör analizinin kullanılabilmesi için belli ön koşullar söz konusudur. Bunlar, örneklem sayısının yeterliliğini anlamak için $\mathrm{KMO}(>0,70$ olmalı) ve Bartlett Küresellik testi$\operatorname{dir}(<0,05$ ile anlamlı bir değer olması gerekir). Araştırma kapsamında kullanılan tüm ölçeklerin KMO değerlerinin tamamının 0,60'tan yüksek (Yapısal Güçlendirme Ölçeği 0,923; İş Yaşamında Yalnızlık Ölçeği 0,906; Beş Faktör Kişilik Ölçeği 0,757) ve Barlett değerleri ise 0,05 önem derecesinde anlamlı (Yapısal Güçlendirme Ölçeği $\chi 2=2474,015$, df=190, p=0,000; İş Yaşamında Yalnızlık Ölçeği $\chi 2=1494,063$, df = 120, p=0,000; Beş Faktör Kişilik 
Ölçeği $\chi 2=3042,606$, df=946, p=0,000) bulunmuştur. Önkoşulların sağlanmasının ardından veri grubu, kullanılan tüm ölçeklerin alt boyutlarını belirlemek amacıyla açımlayıcı (keşfedici) faktör analizi için uygundur (Durmuş vd., 2011).

\section{Yaptsal Güçlendirme Ölçeği Geçerlilik Analizi}

Yapısal Güçlendirme Ölçeği Tolay vd. (2012) tarafından geçerlilik analizine tabi tutulmuş ve orijinalindeki gibi altı faktörlü yapı elde edilmiştir. Faktör analizi sonrasında, madde 17 ve madde 9, orijinal ölçeğe göre farklı boyutlar altında yer aldığı için analizden çıkartılmış ve bu şekilde yeniden analize tabi tutulmuştur.

Tablo 2. Yapısal Güçlendirme Ölçeği Faktör Analizi Sonuçları

\begin{tabular}{|c|c|c|c|c|c|}
\hline $\begin{array}{l}\text { Ölçekte Yer } \\
\text { Aldığı Boyut }\end{array}$ & Yapısal Güçlendirme Ölçeği & F1 & F2 & F3 & F4 \\
\hline \multirow{7}{*}{$\begin{array}{l}\text { Biçimsel/ } \\
\text { Biçimsel } \\
\text { Olmayan Güç } \\
\text { ve Destek }\end{array}$} & $\begin{array}{l}\text { 13. İşinize kattığınız yenilikler için aldığınız ödül } \\
\text { veya teşvikler }\end{array}$ & ,752 & & & \\
\hline & $\begin{array}{l}\text { 15. İşle ilgili faaliyetlerinizin kurum içindeki görü- } \\
\text { nürlüğü }\end{array}$ & ,741 & & & \\
\hline & 14. İşinizdeki esneklik düzeyi & ,737 & & & \\
\hline & 18. Yöneticilerle birlikte sorunlara çözüm arama & ,663 & & & \\
\hline & 7. İyi yaptığınız şeylerle ilgili geri bildirim & 628 & & & \\
\hline & $\begin{array}{l}\text { 16. Eğitim ve/veya araştırma konularında öğretim } \\
\text { üyeleri ile işbirliği yapma }\end{array}$ & ,604 & & & \\
\hline & $\begin{array}{l}\text { 8. Geliştirebileceğiniz şeyler hakkında açıklayıcı bil- } \\
\text { giler }\end{array}$ & 466 & & & \\
\hline \multirow{3}{*}{ Bilgi } & 6. Üst yönetimin amaçları hakkında bilgi & & 888 & & \\
\hline & 5. Üst yönetimin değerleri hakkında bilgi & & 886 & & \\
\hline & 4. Kurumun mevcut durumu hakkında bilgi & & 807 & & \\
\hline \multirow{3}{*}{ Kaynak } & 11. İşin gereklerini yerine getirmek için zaman & & & 828 & \\
\hline & 10. Gerekli evrak işlerini yapmak için zaman & & & ,787 & \\
\hline & 12. İhtiyaç duyduğunuz anlarda yardım & & & 605 & \\
\hline \multirow{3}{*}{ Fursat } & 1. Zorlayıcı ama size katkı sağlayan bir iş & & & & 842 \\
\hline & 2. Yeni bilgi ve beceriler elde edinme şansı & & & & 765 \\
\hline & $\begin{array}{l}\text { 3. Tüm bilgi ve becerilerinizi kullanabileceğiniz gö- } \\
\text { revler }\end{array}$ & & & &, 580 \\
\hline
\end{tabular}

İkinci faktör analizine göre Tablo 2'de görüleceği gibi dört faktörlü bir yapı oluşarak, toplam varyansın\% 70,34'ünü açılamaktadır. Bunun sonucu olarak faktör isimleri "Biçimsel/Biçimsel Olmayan Güç ve Destek", "Bilgi", "Kaynak" ve "Fırsat" alt boyutlarıdır. 


\section{4. İş Yaşamında Yalnızlık Ölçeği Geçerlilik Analizi}

İş Yaşamında Yalnızlık Ölçeği Doğan vd. (2009) tarafından Türkçe'ye uyarlanmıştır. Bu araştırmada da iş yaşamında yalnızlık, orijinalindeki gibi "Duygusal Yoksunluk" ve "Sosyal Arkadaşlık" olarak iki boyutta ele alınmıştır. Bu bilgiler doğrultusunda yapılan ilk faktör analizine göre üç faktörlü bir yapı oluşarak, toplam varyansın\% 62,96'sını açıklamaktadır.

Tablo 3. İş Yaşamında Yalnızlık Ölçeği Faktör Analizi Sonuçları

\begin{tabular}{|c|c|c|c|}
\hline $\begin{array}{l}\text { Ölçekte Yer Aldığı } \\
\text { Boyut }\end{array}$ & İş Yaşamında Yalnızlık Ölçeği & F1 & F2 \\
\hline \multirow{7}{*}{ Duygusal Yoksunluk } & $\begin{array}{l}\text { 4. Kendimi iş arkadaşlarımdan duygusal olarak uzak hissedi- } \\
\text { yorum. }\end{array}$ & 822 & \\
\hline & $\begin{array}{l}\text { 3. Birlikte çalıştığım insanlarla arama mesafe koyduğumu his- } \\
\text { sediyorum. }\end{array}$ & 761 & \\
\hline & $\begin{array}{l}\text { 7. İş arkadaşlarımla birlikteyken çoğu zaman kendimi dışlan- } \\
\text { miş hissediyorum. }\end{array}$ & ,755 & \\
\hline & $\begin{array}{l}\text { 9. İş yerindeyken kendimi genel bir boşluk duygusu içinde his- } \\
\text { sederim. }\end{array}$ & ,752 & \\
\hline & $\begin{array}{l}\text { 2. Çoğunlukla iş arkadaşlarımın bana mesafeli durduklarını } \\
\text { hissediyorum. }\end{array}$ & ,751 & \\
\hline & $\begin{array}{l}\text { 8. İş yerinde çoğu zaman diğer çalışanlarla birlikte aramda bir } \\
\text { kopukluk hissederim. }\end{array}$ & 750 & \\
\hline & $\begin{array}{l}\text { 1. İş ortamında baskı altındayken, iş arkadaşlarım tarafından } \\
\text { yalnız bırakıldığımı hissederim. }\end{array}$ & 669 & \\
\hline \multirow{3}{*}{ Sosyal Arkadaşlık } & $\begin{array}{l}\text { 15. Kendimi iş yerindeki arkadaş grubunun bir parçası olarak } \\
\text { hissederim. (R) }\end{array}$ & & ,881 \\
\hline & $\begin{array}{l}\text { 14. İş yerinde mola zamanlarında beraber vakit geçirebileceğim } \\
\text { biri vardır. }(\mathrm{R})\end{array}$ & & 870 \\
\hline & $\begin{array}{l}\text { 16. İş yerinde beni dinleme zahmetinde bulunan insanlar var- } \\
\text { dır. (R) }\end{array}$ & & ,727 \\
\hline
\end{tabular}

İki faktörlü bir yapı oluşturmak için, madde 5 ve 6 (orijinal ölçekte “Duygusal Yoksunluk" alt boyutunda yer almasına rağmen bu analizde ikinci boyutta yer aldığından), madde 13 (orijinal ölçekte "Sosyal Arkadaşlık" boyutunda yer almasına rağmen bu analizde ilk boyutta yer aldığından), madde 10, 11 ve 12 (bu analizde farklı bir boyut oluşturduğundan) yapılan ikinci analizde listeden çıkartılmıştır. Sonuç olarak, 5, 6, 10, 11, 12 ve 13 nolu maddeler çıartılarak yeniden faktör analizi yapılmıştır. Analiz sonuçları Tablo 3'de listelenmiştir. İkinci faktör analizine göre iki faktörlü 
bir yapı oluşarak toplam varyansın \%65,71'ini açıklamaktadır. Bunun sonucu olarak "Duygusal Yoksunluk" ve "Sosyal Arkadaşlık" alt boyutları belirlenmiştir.

\section{Beş Faktör Kişilik Ölçeği Geçerlilik Analizi}

Beş Faktör Kişilik Ölçeğinin Türkçe'ye uyarlanması, 56 ülke kapsamında kişilerin kendi öztanımlamapofilleri ve modellemeleri konusunda yapılan bir projenin (Schmitt vd., 2007) Türkiye ayağı kapsamında, Sümer ve Sümer (2005) tarafından yapılmıştır.

Tablo 4. Beş Faktör Kişilik Ölçeği Faktör Analizi Sonuçları

\begin{tabular}{|c|c|c|c|c|c|c|}
\hline $\begin{array}{l}\text { Ölçekte Yer Al- } \\
\text { diğ1 Boyut }\end{array}$ & Beş Faktör Kişilik Ölçeği & F1 & F2 & F3 & F4 & F5 \\
\hline \multirow{8}{*}{ Açıklık } & 25. Yaratıcı & 809 & & & & \\
\hline & 30. Sanatsal ve estetik deneyimlere değer veren & ,746 & & & & \\
\hline & 10. Birçok farklı konuya meraklı & ,732 & & & & \\
\hline & 44. Sanat, müzik ve edebiyatta bilgili olan & 712 & & & & \\
\hline & 5. Yeni, orijinal fikirler üreten & 654 & & & & \\
\hline & 20. Hayal gücü yüksek & ,510 & & & & \\
\hline & 41. Sanata ilgisi az olan (R) & 493 & & & & \\
\hline & 40. Fikir yürüten ve fikirlerini açıklamayı seven & 466 & & & & \\
\hline \multirow{6}{*}{ Sorumluluk } & 33. İşleri verimli yapan & & 620 & & & \\
\hline & 28. Görevi tamamlayıncaya kadar sabır gösterebilen & & 612 & & & \\
\hline & 13. Güvenilir bir çalışan & & 607 & & & \\
\hline & 8. Bazen dikkatsiz olabilen (R) & & ,594 & & & \\
\hline & 3. Bir işi titiz yapan & & ,587 & & & \\
\hline & 18. Dağınık olmaya eğilimli (R) & & ,578 & & & \\
\hline \multirow{4}{*}{ Dişadönüklük } & 21. Sessiz bir yapida (R) & & & 792 & & \\
\hline & $\begin{array}{l}\text { 31. Bazen utangaç ve duygularını pek dişa vurmayan } \\
\text { (R) }\end{array}$ & & & ,727 & & \\
\hline & 1. Konuşkan & & & 644 & & \\
\hline & 6. Sosyal ilişkilerinde yakınlaşmaktan kaçınan (R) & & & 613 & & \\
\hline \multirow{4}{*}{ Duygusal Denge } & 4. Depresyonda, hüzünlü & & & & 384 & \\
\hline & 39. Kolayca sinirlenen & & & & 743 & \\
\hline & 14. Gergin olabilen & & & & 696 & \\
\hline & 29. Dakikası dakikasına uymayan & & & & 559 & \\
\hline \multirow{3}{*}{ Uyumluluk } & 22. Genellikle başkalarına güvenen & & & & & ,766 \\
\hline & 42. Başkaları ile işbirliği yapmayı seven & & & & & 489 \\
\hline & 27. Soğuk ve mesafeli olabilen (R) & & & & & 475 \\
\hline
\end{tabular}

Bu araştırmada, orijinal ölçekte olduğu gibi ‘Duygusal Denge”, “Dışadönüklük”, “Açıklık”, “Uyumluluk” ve "Sorumluluk" olarak beş boyutta ele alınmıştır. Bu bilgiler doğrultusunda yapılan ilk faktör analizi sonrasında, 
orijinal faktör yapısına uygunluğunu sağlamak için 26,9 , 38, 34, 24, 37, 2, $23,12,43,19,15,35,32,17,7,16,11,36$ nolu maddeler çıkartılarak yeniden faktör analizi yapılmıştır. Analiz sonuçları Tablo 4'de listelenmiştir. İkinci faktör analizine göre beş faktörlü bir yapı oluşarak toplam varyansın\% 50,94'ünü açıklamaktadır. Bunun sonucu olarak "Açılık", "Sorumluluk", "Dışadönüklük", 'Duygusal Denge" ve "Uyumluluk" alt boyutları belirlenmiştir.

\section{Bulgular}

\section{Araştırma Değişkenleri Arasındaki Korelasyon ve Regresyon Analizi Sonuçları}

Araştırmada kullanılan değişkenler arasındaki ilişkileri ortaya çıkarmak için Pearson korelasyon analizi yapılmıştır. Korelasyon analizinde, Pearson korelasyon katsayısına (r) bakılarak ilişkinin kuvveti ve yönü değerlendirilmiştir. İşaretin pozitif olması, değişkenlerden birinin artması durumunda diğerinin de artacağını veya değişkenlerden birinin azalması durumunda diğerinin de azalacağını gösterir. İşaretin negatif olması ise değişkenler arasında ters yönlü bir ilişki olduğunu ve birinin artması durumunda diğerinin azalacağını gösterir (Büyüköztürk, 2010, s.31-32).

Korelasyon analizi sonuçlarına göre, yapısal güçlendirme ile iş yaşaminda yalnızlık $(r=-0,343 ; p<0,01)$ orta düzeyde ve negatif yönlü anlamlı bir ilişki bulunmaktadır. Yapısal güçlendirme ile "Açılık" arasında $(\mathrm{r}=0,268 ; \mathrm{p}<0,01)$ düşük düzeyde ve pozitif yönlü bir ilişki bulunmaktadır. Yapısal güçlendirme ile "Sorumluluk" arasında $(\mathrm{r}=0,214 ; \mathrm{p}<0,01)$ düşük düzeyde ve pozitif yönlü anlamlı bir ilişki bulunmaktadır. Yapısal güçlendirme ile "Duygusal Denge" arasında $(\mathrm{r}=-0,174 ; \mathrm{p}<0,05)$ düşük düzeyde ve negatif yönlü anlamlı bir ilişki bulunmaktadır. Yapısal güçlendirme ile "Dışadönüklük" ve "Uyumluluk" kişilik özellikleri arasında anlamlı düzeyde bir ilişki bulunmamıştır. İş yaşamında yalnızlık ile "Sorumluluk" arasında $(r=-0,299 ; p<0,01)$ düşük düzeyde ve negatif yönlü bir ilişki bulunmaktadır. İş yaşamında yalnızlık ile "Dışadönüklük" arasında (r=0,250; $\mathrm{p}<0,01)$ düşük düzeyde ve negatif yönlü anlamlı bir ilişki bulunmaktadır. İş yaşamında yalnızlık ile "Duygusal Denge" arasında $(\mathrm{r}=0,325$; $\mathrm{p}<0,01)$ orta düzeyde ve pozitif yönlü anlamlı bir ilişki bulunmaktadır. İş 
yaşamında yalnızlık ile "Uyumluluk" arasında $(\mathrm{r}=-0,355 ; \mathrm{p}<0,01)$ orta düzeyde ve negatif yönlü anlamlı bir ilişki bulunmaktadır. İş yaşamında yalnızlık ile "Açıklık" kişilik özelliği arasında anlamlı düzeyde bir ilişki bulunmamiştır.

Yapısal güçlendirme ile alt boyutları arasındaki ilişki 0,780-0,873 arasinda değişmekte olup yüksek düzeyde ilişkilere işaret etmektedir. İş yaşamında yalnızlık ile alt boyutları arasındaki ilişkide "Duygusal Yoksunluk" 0,884, "Sosyal Arkadaşlik" 0,858 ile yüksek düzeyde tespit edilmiştir.

Hipotezleri test etmek üzere, yapısal güçlendirme ile iş yaşamında yalnızlık arasındaki ilişkide kişilik özelliklerinin aracılık rolünü incelemek için, basit doğrusal regresyon ve çoklu doğrusal regresyon analizleri yapilmıştır.

Baron ve Kenny'e göre (1986) bir değişkenin ara değişken fonksiyonunu yerine getirebilmesi için şu koşulların gerçekleşmesi gerekmektedir; 1-Bağımsız değişkenin, ara değişken olduğu varsayılan değişken üzerinde anlamlı etkisinin olması, 2-Ara değişkenin, bağımlı değişken üzerinde anlamlı etkisinin olması, 3-ïlk iki şartın sağlanması durumunda, bağımsız değişkenin bağımlı değişken üzerindeki etkisinin, ara değişken dâhil edildikten sonra, kaybolmasıdır. Bir başka ifade ile bağımsız ve ara değişkenin aynı anda bağımlı değişken üzerindeki etkisine bakıldığında, eğer bağımsız değişkenin daha önceki etkisi yok olursa tam ara değişken, etkisi azalırsa kısmi ara değişken rolünden bahsedilebilir.

Bununla ilgili her bir hipoteze yönelik yapılan regresyon analizleri aşağıda açıklanmıştır.

- H1: Personel Güçlendirmenin İş Yaşamında Yalnızlık Üzerindeki Etkisinde Kişilik Özelliklerinin Aracılık Rolü vardır.

- H1a:Yapısal güçlendirmenin iş yaşamında yalnızlık üzerindeki etkisinde, açıklık alt boyutunun aracılık rolü vardır hipotezi, açıklık ile iş yaşamında yalnızlık arasında anlamlı ilişki olmadığı için reddedilmiştir.

- H1b: yapısal güçlendirmenin iş yaşamında yalnızlık üzerindeki etkisinde, sorumluluk alt boyutunun aracılık rolü vardır hipotezi, ilk iki şartı sağladığı için regresyon analizine tabi tutulmuş olup sonuçları Tablo 5'de gösterilmiştir.

Bu analizin sonuçlarına göre ilk aşamada (Model 1) yapısal güçlendirmenin (bağımsız değişken), sorumluluk (ara değişken) üzerinde anlamlı 
bir etkisi olduğu tespit edilmiş olup yapısal güçlendirme düzeyi, sorumluluk düzeyini artırmaktadır $(\beta=0,214 ; \mathrm{p}<0,01)$. Ayrıca yapısal güçlendirme, sorumluluk değişkenindeki varyansın \%4,6 (Düzeltilmiş $\left.\mathrm{R}^{2}=0,040\right)^{\prime}$ lık bir kısmını açıklamaktadır. İkinci aşamada (Model 2) sorumluluk değişkeninin (bağımsız değişken), iş yaşamında yalnızlık (bağımlı değişken) üzerinde anlamlı bir etkisi tespit edilmiş olup sorumluluk düzeyinin artması, iş yaşamında yalnızlık düzeyini azaltmaktadır $(\beta=-0,299$; $\mathrm{p}<0,01)$.

Tablo 5. Yapısal Güçlendirme, İş Yaşamında Yalnızlık ve Sorumluluk Değişkenleri Arasındaki Regresyon Analizi Sonuçları

\begin{tabular}{|c|c|c|c|c|c|c|c|}
\hline $\begin{array}{l}\text { Mo- } \\
\text { del }\end{array}$ & Bağımsız Değişken & \multicolumn{6}{|c|}{ Bağımlı Değişken } \\
\hline \multirow{5}{*}{1} & \multirow{5}{*}{ Yapısal Güçlendirme } & \multicolumn{6}{|c|}{ Sorumluluk (Ara Değişken) } \\
\hline & & $\beta$ & $\underline{T}$ & $\mathrm{p}$ & $\underline{\mathrm{R}^{2}}$ & $\frac{\text { Düzeltilmiş }}{\underline{\mathrm{R}}^{2}}$ & $\underline{F}$ \\
\hline & & 0,214 & 2,902 & 0,004 & 0,046 & 0,040 & 8,422 \\
\hline & & \multicolumn{6}{|c|}{ İş Yaşamında Yalnızlık } \\
\hline & & $\underline{\beta}$ & $\underline{T}$ & $\underline{p}$ & $\underline{R^{2}}$ & $\frac{\text { Düzeltilmis }}{\underline{\mathrm{R}}^{2}}$ & $\underline{F}$ \\
\hline \multirow[t]{3}{*}{2} & Sorumluluk & $-0,299$ & $-4,138$ & 0,000 & 0,089 & 0,084 & 17,127 \\
\hline & & \multicolumn{6}{|c|}{ İş Yaşamında Yalnızlık } \\
\hline & & $\underline{\beta}$ & $\underline{T}$ & $\mathrm{p}$ & $\underline{R^{2}}$ & $\frac{\text { Düzeltilmiş }}{\underline{\mathrm{R}}^{2}}$ & $\underline{F}$ \\
\hline \multirow[t]{3}{*}{3} & Yapısal Güçlendirme & $-0,343$ & $-4,823$ & 0,000 & 0,117 & $0, \overline{112}$ & 23,263 \\
\hline & & \multicolumn{6}{|c|}{ İş Yaşamında Yalnızlık } \\
\hline & & $\underline{\beta}$ & $\underline{T}$ & $\mathrm{p}$ & $\underline{\mathrm{R}^{2}}$ & $\frac{\text { Düzeltilmis }}{\underline{\mathrm{R}}^{2}}$ & $\underline{F}$ \\
\hline \multirow[t]{2}{*}{4} & Yapısal Güçlendirme & $-0,292$ & $-4,130$ & 0,000 & \multirow{2}{*}{0,170} & \multirow[t]{2}{*}{0,161} & \multirow{2}{*}{17,879} \\
\hline & Sorumluluk & $-0,236$ & $-3,339$ & 0,001 & & & \\
\hline
\end{tabular}

İş Yaşamında Yalnızlık= 4,306 - Yapısal Güçlendirme*0,292 - Sorumluluk*0,236

Ayrıca sorumluluk, iş yaşamında yalnızlıktaki varyansın \%8,9 (Düzeltilmiş $\left.\mathrm{R}^{2}=0,084\right)^{\prime} l u ̈ k$ bir kısmını açıklamaktadır. Üçüncü aşamada (Model 3) yapısal güçlendirmenin (bağımsız değişken), iş yaşamında yalnızlık (bağımlı değişken) üzerinde anlamlı bir etkisi tespit edilmiş olup yapısal güçlendirme düzeyinin artması, iş yaşamında yalnızlık düzeyini azaltmaktadır $(\beta=-0,343 ; \mathrm{p}<0,01)$. Ayrıca yapısal güçlendirme, iş yaşamında yalnızlıktaki varyansın \%11,7 (Düzeltilmiş $R^{2}=0,112$ )'lik bir kısmını açılamaktadır. Son aşamada (Model 4) yapısal güçlendirme ve sorumluluk 
bağımsız değişkenler, iş yaşamında yalnızlık bağımlı değişken olacak şekilde çoklu doğrusal regresyon analizine tabi tutulmuştur ve yapısal güçlendirmenin etkisinin anlamlı şekilde devam ettiği fakat etkisinin azaldığ1 görülmüştür $(\beta=-0,292 ; p<0,01)$. Bunun sonucu olarak yapisal güçlendirme ve iş yaşamında yalnızlık arasındaki ilişkide, kişilik özelliklerinden sorumluluğun kısmi ara değişken rolü üstlendiği söylenebilir. Araştırmadaki H1b hipotezi kabul edilmiştir.

H1c:Yapısal güçlendirmenin iş yaşamında yalnızlık üzerindeki etkisinde, dışadönüklük alt boyutunun aracılık rolü vardır hipotezi, dışadönüklük ile yapısal güçlendirme arasında anlamlı ilişki olmadığ 1 için reddedilmiştir.

H1d:Yapısal güçlendirmenin iş yaşamında yalnızlık üzerindeki etkisinde, duygusal denge alt boyutunun aracılık rolü vardır hipotezi, ilk iki şartı sağladığı için regresyon analizine tabi tutulmuş olup sonuçları Tablo 6 'da gösterilmiştir.

Tablo 6. Yapısal Güçlendirme, İş Yaşamında Yalnızlık ve Duygusal Denge Değişkenleri Arasındaki Regresyon Analizi Sonuçları

\begin{tabular}{|c|c|c|c|c|c|c|c|}
\hline \multicolumn{2}{|c|}{ Model Bağımsız Değişken } & \multicolumn{6}{|c|}{ Bağımlı Değişken } \\
\hline & & \multicolumn{6}{|c|}{ Duygusal Denge (Ara Değişken) } \\
\hline \multirow[b]{2}{*}{1} & \multirow[b]{2}{*}{ Yapisal Güçlendirme } & $\underline{\beta}$ & $\mathrm{t}$ & $p$ & $\underline{\mathrm{R}^{2}}$ & Düzeltilmiş $\mathrm{R}^{2}$ & $\underline{F}$ \\
\hline & & $-0,174$ & $-2,333$ & 0,021 & 0,030 & 0,025 & 5,441 \\
\hline \multirow{5}{*}{2} & & \multicolumn{6}{|c|}{ İş Yaşamında Yalnızlık } \\
\hline & & $\underline{\beta}$ & $\underline{\mathrm{t}}$ & $\underline{p}$ & $\underline{R^{2}}$ & 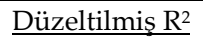 & $\underline{F}$ \\
\hline & Duygusal Denge & 0,325 & 4,543 & 0,000 & 0,106 & 0,100 & 20,643 \\
\hline & & \multicolumn{6}{|c|}{ İş Yaşamında Yalnızlık } \\
\hline & & $\underline{\beta}$ & $\underline{t}$ & $\mathrm{p}$ & $\underline{\mathrm{R}^{2}}$ & ${\text { Düzeltilmiş } \mathrm{R}^{2}}$ & $\underline{F}$ \\
\hline \multirow[t]{3}{*}{3} & Yapısal Güçlendirme & $-0,343$ & $-4,823$ & 0,000 & 0,117 & 0,112 & 23,263 \\
\hline & & \multicolumn{6}{|c|}{ İş Yaşamında Yalnızlık } \\
\hline & & $\underline{\beta}$ & $\underline{t}$ & $\mathrm{p}$ & $\underline{\mathrm{R}^{2}}$ & ${\text { Düzeltilmiş } \mathrm{R}^{2}}^{2}$ & $\underline{F}$ \\
\hline \multirow[t]{2}{*}{4} & Yapısal Güçlendirme & $-0,295$ & $-4,258$ & 0,000 & \multirow{2}{*}{0,190} & \multirow{2}{*}{0,190} & \multirow{2}{*}{20,398} \\
\hline & Duygusal Denge & 0,274 & 3,949 & 0,000 & & & \\
\hline
\end{tabular}

İş Yaşamında Yalnızlık= 2,285 - Yapısal Güçlendirme*0,295 +Duygusal Denge*0,274

Bu analizin sonuçlarına göre ilk aşamada (Model 1) yapısal güçlendirmenin (bağımsız değişken), duygusal denge (ara değişken) üzerinde anlamlı bir etkisi olduğu tespit edilmiş olup yapısal güçlendirme düzeyinin artması, duygusal denge düzeyini azaltmaktadır $(\beta=-0,174 ; \mathrm{p}<0,05)$. Ayrıca yapısal güçlendirme, duygusal denge değişkenindeki varyansın \%3,0 
(Düzeltilmiş $\left.\mathrm{R}^{2}=0,025\right)^{\prime} 1$ lk bir kısmını açıklamaktadır. İkinci aşamada (Model 2) duygusal denge değişkeninin (bağımsız değişken), iş yaşamında yalnızlık (bağımlı değişken) üzerinde anlamlı bir etkisi tespit edilmiş olup duygusal denge düzeyinin artması, iş yaşamında yalnızlık düzeyini artırmaktadır $(\beta=0,325 ; p<0,01)$. Ayrıca duygusal denge, iş yaşamında yalnızlıktaki varyansın \%10,6 (Düzeltilmiş $\mathrm{R}^{2}=0,100$ )'lık bir kısmını açılamaktadır. Üçüncü aşamada (Model 3) yapısal güçlendirmenin (bağımsız değişken), iş yaşamında yalnızlık (bağımlı değişken) üzerinde anlamlı bir etkisi tespit edilmiş olup yapısal güçlendirme düzeyinin artması, iş yaşamında yalnızlık düzeyini azaltmaktadır $(\beta=-0,343 ; p<0,01)$. Ayrıca yapısal güçlendirme, iş yaşamında yalnızlıktaki varyansın \%11,7 (Düzeltilmiş $\mathrm{R}^{2}=0,112$ )'lik bir kısmını açılamaktadır. Son aşamada (Model 4) yapısal güçlendirme ve duygusal denge bağımsız değişkenler, iş yaşamında yalnızlık bağımlı değişken olacak şekilde çoklu doğrusal regresyon analizine tabi tutulmuştur ve yapısal güçlendirmenin etkisinin anlamlı şekilde devam ettiği fakat etkisinin azaldığı görülmüştür $(\beta=-0,295 ; p<0,01)$. Bunun sonucu olarak yapısal güçlendirme ve iş yaşamında yalnızlık arasındaki ilişkide, kişilik özelliklerinden duygusal dengenin kısmi ara değişken rolü üstlendiği söylenebilir. Araştırmadaki H1d hipotezi kabul edilmiştir.

H1e:Yapısal güçlendirmenin iş yaşamında yalnızlık üzerindeki etkisinde, uyumluluk alt boyutunun aracılık rolü vardır hipotezinde, uyumluluk ile yapısal güçlendirme arasında anlamlı ilişki olmamasına rağmen, alt boyutlar arasındaki ilişkiler incelendiğinde uyumluluk özelliğinin, yapısal güçlendirmenin bilgi boyutu $(\beta=0,165 ; p<0,05)$ ile genel iş yaşamında yalnızlık $(\beta=-0,355 ; p<0,01)$ ve iş yaşamında yalnızlığın duygusal yoksunluk $(\beta=-0,354 ; p<0,01)$ boyutu arasında kısmi aracılık, sosyal arkadaşlık boyutu $(\beta=-0,261 ; p<0,01)$ arasında ise tam aracılıkrolü tespit edilmiştir. Benzer şekilde, uyumluluk özelliğinin, kaynak boyutu $(\beta=0,170 ; \mathrm{p}<0,05)$ ile genel iş yaşamında yalnızlık $(\beta=-0,355 ; p<0,01)$ ve iş yaşamında yalnızlığın duygusal yoksunluk $(\beta=-0,354 ; p<0,01)$ ve sosyal arkadaşlık boyutları $(\beta=-$ $0,261 ; p<0,01)$ arasında kısmi ara değişken rolü tespit edilmiştir. Araştırmadaki H1e hipotezi kısmi kabul edilmiştir.

Bulgular sonucunda elde edilen ara değişken rolleri Şekil 2'de numaralandırılarak gösterilmiştir. 


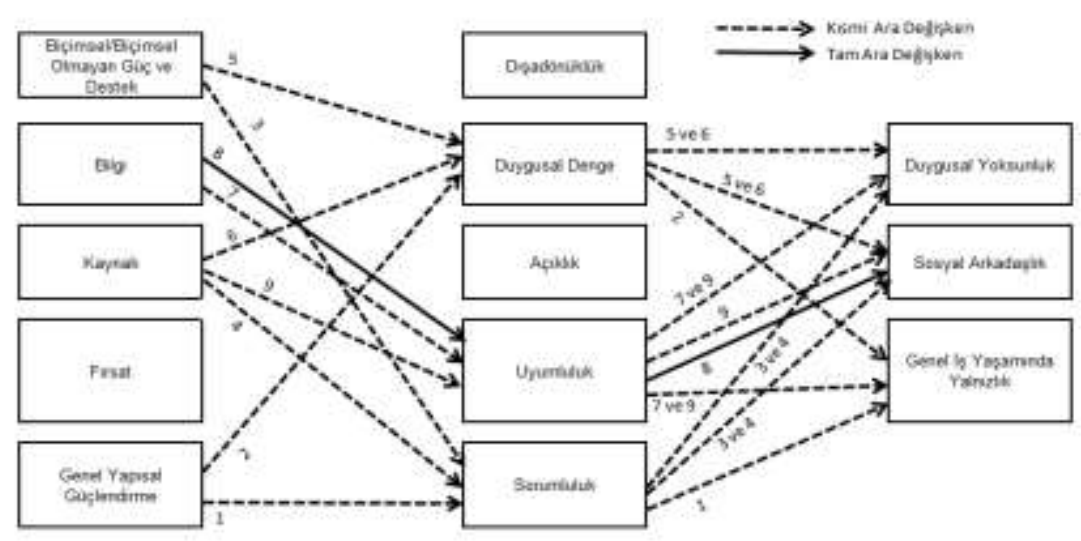

Şekil 2: Tüm Ara Değişken Rolleri

Bulgular 1şığında; (1)- Sorumluluk özelliği, genel yapısal güçlendirme ile genel iş yaşamında yalnızlık arasında kısmi (H1b hipotezi), (2)- Duygusal denge özelliği, genel yapısal güçlendirme ile genel iş yaşamında yalnızlık arasında kısmi (H1d Hipotezi), (3)- Sorumluluk özelliği, "Biçimsel/Biçimsel Olmayan Güç ve Destek" boyutu ile duygusal yoksunluk ve sosyal arkadaşlık ilişkilerinde kısmi, (4)- Sorumluluk özelliği, kaynak boyutu ile duygusal yoksunluk ve sosyal arkadaşlık boyutları arasında kısmi, (5)- Duygusal denge özelliği, “Biçimsel/Biçimsel Olmayan Güç ve Destek” boyutu ile duygusal yoksunluk ve sosyal arkadaşlık boyutları arasında, kısmi, (6)- Duygusal denge özelliği, kaynak boyutu ile duygusal yoksunluk ve sosyal arkadaşlık boyutları arasında kısmi, (7)- Uyumluluk özelliği, bilgi boyutu ile genel iş yaşamında yalnızlık ve onun duygusal yoksunluk alt boyutu arasındaki ilişkide kısmi ara değişken rolündedir. (8)- Bu araştırmadaki tüm ilişkiler düşünüldüğünde tam ara değişken çıkan tek özellik, bilgi boyutu ile sosyal arkadaşlık boyutu arasındaki ilişkide uyumluluk özelliğidir. (9)- Uyumluluk özelliği, kaynak boyutu ile genel iş yaşamında yalnızlık ve onun duygusal yoksunluk ve sosyal arkadaşlık boyutları arasindaki ilişkide kısmi ara değişken rolündedir.

H2: Değişkenlerin her biri, demografik özelliklere göre farklılık göstermektedir hipotezini test etmek üzere, aşağıdaki bölümde farklılaşma analizleri yapılmıştır. 


\section{Tüm Değişkenlerin Demografik Özelliklere Göre Farklılaşması}

Yapısal güçlendirme, iş yaşamında yalnızlık ve kişilik özellikleri değişkenlerinin, demografik özelliklere göre farklılaşması ile ilgili bulgular şu şekilde sıralanabilir. Araştırmaya katılanların demografik özelliklerinin alt gruplarındaki örneklem sayılarının dağılımı $N>=30$ olanlar için bağımsız gruplar T testi ve tek yönlü varyans analizi (ANOVA) testleri kullanılmıştır. Ayrıca, Levene testi ile varyansların homojenliğine bakılarak, farklılaşma sonuçları buna göre değerlendirilmiştir. Anlamlı farklılık gösteren alt gruplar arasındaki anlamlllık düzeyini incelemek üzere homojen varyanslı örneklem grupları için Post Hoc-Scheffe, homojen varyanslı olmayan örneklem grupları için Post Hoc-Tamhane's çoklu karşılaştırma analizlerine başvurulmuştur (Kayri, 2009).

Araştırmaya katılanların genel yapısal güçlendirme düzeylerinin cinsiyet, medeni durum, eğitim, personel statüsü (Mavi/Beyaz Yakalı), İş yerinde çalışma süresi (kıdem), sektör ve yönetici değişkenlerine göre anlamlı farklılık bulunmamıştır. Yaş değişkenine göre ise genel yapısal güçlendirme düzeyleri anlamlı bir farklılık oluşturmuş $(F=3,929 ; \mathrm{p}<0,05)$ ve Post Hoc analizi sonrasinda bu farklılığın kaynak alt boyutunun "30 ve Altı" $(\bar{X}=3,37)$ ile "40 ve Üzeri" $(\bar{X}=3,89)$ yaş grupları arasında oluştuğu tespit edilmiştir. Benzer şekilde alt boyutlar açısından incelendiğinde eğitim değişkenine göre kaynak alt boyutunun "Orta Öğretim" ( $\bar{X}=4,08)$, "Lisans" $(\overline{\mathrm{X}}=3,55)$ ve "Yüksek Lisans/Doktora" $(\overline{\mathrm{X}}=3,44)$ grupları arasında $(\mathrm{F}=3,870 ; \mathrm{p}<0,05)$, sektörler göz önüne alındığında "Ana Metal Sanayi" $(\bar{X}=3,40)$ ile "İmalat" $(\bar{X}=3,92)$ sektörleri arasında $(\mathrm{F}=3,407 ; \mathrm{p}<0,05)$, kaynak $(\mathrm{t}=2,129 ; \mathrm{p}<0,05)$ ve bilgi $(\mathrm{t}=-2,193 ; \mathrm{p}<0,05)$ alt boyutlarının çalışanın mavi yakalı $(\bar{X}=3,89)$ veya beyaz yakalı $(\bar{X}=3,55)$ statüsünde olmasına göre, yönetici düzeyinde olanlar $(\bar{X}=3,65)$ ile olmayan $(\bar{X}=3,23)$ çalışanlar arasında ise bilgi boyutuna göre anlamlı farklılıklar elde edilmiştir $(t=2,290 ; p<0,05)$.

Araştırmaya katılanların genel iş yaşamında yalnızlık düzeylerinin cinsiyet, yaş, medeni durum, eğitim, personel statüsü (Mavi/Beyaz Yakalı), sektör ve yönetici değişkenlerine göre anlamlı farklılaşma tespit edilmemiştir. İş yerinde çalışma süresi (kıdem)değişkenine göre ise genel iş yaşamında yalnızlık düzeyleri anlamlı bir farklılık oluşturmuş ( $\mathrm{F}=5,371$; $\mathrm{p}<0,01)$ ve Post Hoc analizi sonrasinda bu farklılığın "5 Y1l ve Altı" $(\bar{X}=2,01)$, "6-12 Y1l” ( $\bar{X}=1,57)$ ve "13 Yıl ve Üzeri" $(\bar{X}=2,10)$ grupları arasında 
oluştuğu tespit edilmiştir. Aynı gruplar arasında duygusal yoksunluk alt boyutunun da farklılaştığı $(F=6,691 ; p<0,01)$ görülmüş olup en yüksek duygusal yoksunluğun $(\overline{\mathrm{X}}=2,26)$ " 5 Yıl ve Altı" kıdeme sahip çalışanda oluştuğu görülmüştür.

Araştırmaya katılanların cinsiyet,yaş, medeni durum, İş yerinde çalışma süresi (kıdem)ve yönetici değişkenlerine göre hiçbir kişilik özelliği anlamlı bir farklılık oluşturmamıştır. Bununla birlikte personel statüsüne göre açılılk ( $\mathrm{t}=-2,441 ; \mathrm{p}<0,05)$ özelliğinin mavi yakalı $(\overline{\mathrm{X}}=3,71)$ ve beyaz yakalı $(\bar{X}=3,96)$, sorumluluk $(t=4,359 ; \mathrm{p}<0,01)$ özelliğinin mavi yakalı $(\overline{\mathrm{X}}=4,36)$ ve beyaz yakalı $(\bar{X}=4,00)$, dışadönüklük $(t=-2,856 ; p<0,01)$ özelliğinin mavi yakalı $(\bar{X}=3,35)$ ve beyaz yakalı $(\bar{X}=3,70)$, uyumluluk $(t=-2,354 ; \mathrm{p}<0,05)$ özelliğinin mavi yakalı $(\overline{\mathrm{X}}=3,41)$ ve beyaz yakalı $(\overline{\mathrm{X}}=3,70)$ grupları arasında anlamlı farklılık tespit edilmiştir. Eğitim değişkenine göre açıklık özelliği $(\mathrm{F}=3,187 ; \mathrm{p}<0,05)$ "Orta Öğretim" $(\overline{\mathrm{X}}=3,62)$ ile "Yüksek Lisans/Doktora" $(\bar{X}=4,05)$ grupları arasında, sorumluluk özelliği $(F=9,798 ; p<0,01)$ “Orta Ö $\breve{g}-$ retim" ( $\overline{\mathrm{X}}=4,51)$, “Lise ve Dengi" $(\overline{\mathrm{X}}=4,09)$, “Lisans" $(\overline{\mathrm{X}}=4,00)$ ve "Yüksek Lisans/Doktora" ( $\bar{X}=3,97)$ grupları arasında, dışadönüklük özelliği ( $\mathrm{F}=5,130$; $\mathrm{p}<0,01)$ ise "Lise ve Dengi" $(\overline{\mathrm{X}}=3,23)$ ile "Lisans" $(\overline{\mathrm{X}}=3,79)$ grupları arasında anlamlı farklılık göstermiştir. Sektörler göz önüne alındığında "İmalat" $(\bar{X}=3,68)$ ile "Toptan ve Perakende Ticaret" $(\bar{X}=4,09)$ sektörleri arasında açıklık özelliğine göre anlamlı farklılaşma oluşmuştur ( $\mathrm{F}=4,007 ; \mathrm{p}<0,01)$. "Ana Metal Sanayi" $(\bar{X}=3,97)$, “İmalat" $(\bar{X}=4,36)$, “Eğitim" $(\bar{X}=4,01)$ ve “Toptan ve Perakende Ticaret" ( $\bar{X}=3,93)$ sektörlerinde sorumluluk özelliğine göre anlamlı farklık oluşmuştur ( $F=7,864 ; \mathrm{p}<0,01)$. Dişadönüklük özelliği açısından "İmalat" ( $\overline{\mathrm{X}}=3,37)$ ve "Toptan ve Perakende Ticaret" $(\bar{X}=3,83)$ sektörleri arasında anlamlı farklılık tespit edilmiştir ( $F=3,358$; $\mathrm{p}<0,05)$.

Analizler sonrasında H2 hipotezi kısmi olarak kabul edilmiştir.

\section{Tartışma ve Sonuç}

Daha önceki araştırmalarda her birinin ayrı olarak ele alındığı pek çok çalışma bulunmakla birlikte, bu araştırmada kurulan model aracılığı ile personel güçlendirme, kişilik özellikleri ve iş yaşamında yalnızlık kavramı bir arada incelenerek, literatürde bir boşluğu doldurmaya katkı sağlaması amaçlanmıştır. Böylece kişilik özelliklerinin aracı ve düzenleyici rollerinin 
araştırılmasında bu çalışma bir örnek teşkil edebilecektir. Ayrıca, gelecekte personel statüsü veya sektörler bazında yapılacak benzer nitelikteki araştırmalara da zemin oluşturacağı düşünülmektedir.

Alt boyutlar açısından tüm ara değişken rolleri incelenmiş (Bknz: Şekil 2) ve bunun sonucunda (1) numaralı ilişkiye göre yapısal güçlendirmenin artması, çalışandaki sorumluluk özelliğini artırmakta bu özellik de kişilerin iş yerinde kendilerini daha az yalnız hissetmelerini sağlamaktadır. Sorumluluğun, personel statüsünün mavi veya beyaz yakalı olmasına, eğitim düzeyine ve sektöre göre farklllık gösterdiği göz önünde bulundurulduğunda önemli bir kişilik özelliği olarak görülmektedir. Özellikle "İmalat", "Eğitim" ve "Toptan ve Perakende Ticaret" sektörlerinde çalışanların güçlendirilmesi, bu çalışanların işlerinde daha dikkatli, azimli, başarı odaklı ve sistemli olmalarına ve iş yerinde daha az yalnız hissetmelerine katkı sağlayacağı düşünülmektedir. Bununla birlikte sorumluluk, tam aracılık rolü yerine kısmi aracılık rolü üstelendiğinden bu durum, güçlendirme ve yalnızlık arasındaki ilişkide başka faktörlerin olduğunu da göstermektedir. (2) numaralı ilişkinin göstergesi olarak, yapısal güçlendirmenin artması, çalışanın duygusal denge halini olumlu etkilemekte ve kişi kendisini iş yerinde yalnız hissetmemektedir. Çalışanın güçsüz hale getirilmesi ise onu, daha endişeli, kaygılı ve defresif duygu haline getirebileceği için, yalnızlığı daha fazla hissedebilecektir. Fakat kısmi aracılık rolünden dolayı, bu ilişkide başka faktörlerin varlığ 1 da söz konusudur. (3) numaralı ilişkiden dolayı, örgüt tarafından çalışanın görünürlüğünün sağlanması, işinde inisiyatif almasına imkân verilmesi, ekip arkadaşları ile birlikte sorunlara çözüm yolları aranması, çalışanın işine daha özen göstermesine, iş yerindeki diğer çalışanlarla bire bir ve grup iletişimlerinde, daha yakın ilişkiler kurabilmesine katkı sağlayacaktır. Ayrıca, sorumluluk özelliğinin tüm eğitim düzeylerinde anlamlı farklılık gösterdiği bulgusu dikkate alındığında, eğitim seviyesinin artması ile birlikte sorumluluk özelliğinin azalması, ilginç bir bulgu olarak görülmektedir. (4) numaralı ilişkinin sonucu olarak, çalışanların işlerini daha etkili bir şekilde yapabilmeleri için gerekli olan bütçe, zaman, insan ve malzeme kaynaklarının sağlanması suretiyle, çalışanların sorumluluk özelliklerinin artacağı ve iş yerinde gerek bireysel gerekse de sosyal ortamlarda, kendilerini daha az yalnız hissedecekleri düşünülmektedir. Çalışanların iş yeri kıdemlerinin, genel iş yaşamında yalnızlık ve duygusal yoksunluk boyutunda anlamlı 
farklılık gösterdiği ve yalnızlı̆̆ın en çok " 5 Yıl ve Altı" grupta hissedildiği bulgusu dikkate alındığında, bu gruba sağlanacak kaynakların, çok daha önemli olacağ1 söylenebilir. Fakat kısmi ara değişken özelliğinden dolayı burada, başka değişkenlerin varlığ 1 da söz konusudur. (5) numaralı ilişki dikkate alındığında, örgütün çalışanlarına sağlayacağı ödül ve teşvikler, farklı kurumlarla iş birliği yapabilme olanaklarının artması, katılımlarının sağlanması, çalışanların duygusal dengelerine olumlu katkı sağlayacak ve gerek duygusal gerekse de sosyal açıdan yalnız hissetmeyeceklerdir. (6) numaralı ilişki sonucunda çalışanlara, işlerini yapabilmeleri için gerekli olan kaynakların sağlanması durumunda, karşı tarafa güvenmeme, kaygı, korku gibi olumsuz duygular azalacak, böylece iş yerindeki bire bir ve grup içi ilişkilerinde kendilerini yalnız hissetmeyeceklerdir. İş yeri kıdeminin duygusal yoksunluk boyutunda anlamlı şekilde farklılaştığı bulgusundan yola çıkarak, kendilerini en az yalnız hisseden grup "6-12 Y11" grubu olarak görülmektedir. Bu durumda, en fazla kaynağın bu kıdeme sahip çalışanlara tahsis edildiği düşünülebilir. (7) numaralı ilişkinin göstergesi olarak, çalışanlara işleriyle ilgili gerekli bilgilerin sağlanması durumunda, kişiler kendilerini daha güvenli bulacak, başkalarıyla olan ilişkilerinde daha kibar ve samimi olacak böylece iş yerinde kendilerini yalnız hissetmeyeceklerdir. Ayrıca, uyumluluk özelliğinin personel statüsüne göre anlamlı farklılık gösterdiği bulgusundan yola çıkıldığında, beyaz yakalı çalışanların uyumluluk düzeylerinin daha yüksek olduğu, bunun sebebinin de kendilerine sağlanan bilgi düzeyinin daha yüksek olduğu söylenebilir. Fakat bu ilişkide, kısmi aracılık rolünden dolayı başka değişkenlerin varlığından söz edilebilir. (8) numaralı ilişki açısından tam ara değişken çıkan tek özellik, bilgi boyutu ile sosyal arkadaşlık boyutu arasındaki ilişkide uyumluluk özelliğidir. Buradan yola çıkarak, örgüt içerisinde bilgi düzeyi artırılmış bir çalışanın, uyumluluk özelliğinin de olumlu etkisiyle, bu bilgisini sosyal ilişkilerinde etkin olarak kullanabildiğini ve kendisini yalnızlık duygusundan uzaklaştırdığını söylemek mümkündür. (9) numaralı ilişkinin göstergesi olarak, gerekli kaynaklarla donatılmış veya onlara rahat erişilebilme imkânı sağlanmış bir çalışanın uyumluluk özelliği gelişmekte ve kendisini iş yerinde daha az yalnız hissetmektedir. Fakat kısmi aracılık rolü dolayısı ile bu ilişkide farklı faktörlerin de varlığından söz edilebilir. 
$\mathrm{Bu}$ araştırmanın bazı kısıtları bulunmaktadır. Öncelikle veriler anket aracılığı ile toplandığından yaygın metot yanılgısı yaşanmış olması mümkündür. Araştırma yorumlarımız, örneklem sayısıyla sınırlıdır. Kolayda örnekleme yönteminin seçilmiş olması da araştırma sonuçlarının genellenebilirliğini engellemiştir. Ayrıca, oluşturulan model daha önce Türkçe yazında araştırılmamış ve yeni önerilen bir model olmasından dolayı geçerliliğinin sınanması amacıyla benzer çalışmalarla ve farkı değişkenlerle desteklenmelidir. 


\title{
EXTENDED ABSTRACT
}

\section{The Mediating Effect of Personality Traits on The Relationship Between Employee Empowerment and Loneliness in The Workplace}

\author{
Emine Sever - Mahmut Paksoy \\ *
}

Istanbul Kültür University

In today's business life, vertical organizations have begun to leave their place to horizontal communication channels, making it necessary for employees to take more effective roles in the organization, to participate in decision-making mechanisms, to provide easier access to information sources and to provide opportunities to increase self-sufficiency levels. As a result, empowerment is considered as an important subject in the literature of organizational behavior.

The concept of personnel empowerment is based on two basic approaches, "psychological" and "structural" (Menon, 2001, p.155). In this research, the issue of structural strengthening was discussed. The main reason for this is that structural empowerment is related to the organizational dimension and that the organization may have a shaping power over the personality of the employee (Arthur et al., 1989, p.238). In this context, although there is no study that directly examines the effect of structural empowerment on personality traits, it is known that empowerment of employees increases self-efficacy awareness. Conger and Kanungo's (1988, p. 480) suggest that the impact of empowerment on certain personality behaviors, such as patience and perseverance, to initiate an action and to maintain it is considered, as this is thought to be related toresponsibility indent of personality traits. Innovative thinking and mental curiosity, which is also related to openness, Dan et al. (2018) and it is concluded that the perception of high structural strengthening increases the innovative thinking.

Individuals exhibit their personal characteristics in situations they encounter in business life. Thus, it is possible to state that personality traits can have a significant effect on perception of loneliness in business life. 
Wright (2005) states that the perception of loneliness occurs in business life as a result of the effects of individual, organizational and environmental factors on individuals. In the literature, there are many studies examining the relationship between personality traits and loneliness in business life (Levin and Stokes, 1986; Bell et al., 1990; Cheng and Furnham, 2002; Özçelik and Barsade, 2011; Zhou, 2018). When the findings of these researches were examined, it was found that the significant effect of personality traits on loneliness in business life was an important issue to be investigated and contributed to the establishment of the research model.

Another important issue in the formation of the hypotheses and model in the article was the relationship between structural strengthening and loneliness in business life. Although there is no research examining these two variables on the same model, there are studies in the literature showing that they can be linked. For instance, according to Kanter's approach, structural empowerment has six dimensions: opportunity, knowledge, resource, support, formal and informal power. With this in mind, O'Brain (2010, p.6) defines structural strengthening as an organizational capability that provides access to these elements. According to Lashinger (2010, p.6), employees feel weak, hopeless and frustrated if they cannot reach these elements. Negative attitudes and behaviors such as absenteeism, high intention to quit, reduced loyalty to the organization and job satisfaction occur. Loneliness in business life is also a subject with negative attitudes. In addition to this information, a significant negative relationship between structural empowerment and intention to quit (Cai and Zhou, 2009) and a positive significant relationship between loneliness and intention to quit (Erdirençelebi and Ertürk, 2018). The researchers in this article have assumed that there may be a meaningful relationship between structural strengthening and business life alone.

In the light of this information, it is possible to state that the relationship between structural strengthening and loneliness in work life constitutes an important place in organizational life. However, it was preferred to examine the relationship between them through personality traits rather than directly. Since there is no model that deals with these three variables at the same time, it is aimed to eliminate this gap in the literature and a research model has been established in this direction. 
Pearson correlation analysis was performed to reveal the relationships between the variables used in the study. In correlation analysis, the strength and direction of the relationship was evaluated by looking at the Pearson correlation coefficient (r). A positive sign indicates that if one of the variables increases, the other will increase or if one of the variables decreases, the other decreases. Negative sign indicates that there is an inverse relationship between variables and if one increases, the other decreases (Büyüköztürk, 2010, p. 31-32).

According to the results of correlation analysis, there is a moderate and negative relationship between structural empowerment and loneliness in the workplace $(\mathrm{r}=-0.343 ; \mathrm{p}<0.01)$. There is a low positive correlation between structural empowerment and "openness" ( $r=0.268 ; \mathrm{p}<0.01)$. There is a low-level positive correlation between structural empowerment and "Conscientiousness" $(r=0.214 ; \mathrm{p}<0.01)$. There was a significant negative correlation between structural empowerment and "Emotional Stability" ( $\mathrm{r}$ $=-0,174 ; \mathrm{p}<0.05$ ). There was no significant relationship between structural empowerment and "Extraversion" and "Agreeableness" personality traits. There is a low and negative relationship between loneliness and "Conscientiousness" $(\mathrm{r}=-0.299 ; \mathrm{p}<0.01)$. Loneliness in the workplace and ad "Extraversion" ( $\mathrm{r}=-0.250 ; \mathrm{p}<0.01)$, there is a significant low-level and negative relationship. There was a moderate and positive relationship between loneliness in the workplace and "Emotional Stability" $(r=0.325 ; \mathrm{p}$ $<0.01)$. There was a moderate and negative relationship between loneliness in the workplace and "Agreeableness" $(r=-0.355 ; \mathrm{p}<0.01)$. There was no significant relationship between loneliness in the workplace and “Openness" personality trait.

Although there are many studies in the previous studies, each of which is discussed separately, the aim of the study is to contribute to filling a gap in the literature by examining personnel empowerment, personality traits and the concept of loneliness in work life through the model established in this research. Thus, this study may serve as an example in investigating the mediator and regulatory roles of personality traits. In addition, it is thought that it will provide a basis for future research based on personnel status or sectors. 


\section{Kaynakça / References}

Andersson, L. (1993). Loneliness and its relationship with misery. Psychological Reports, 73, 584-586.

Aytaç, S. (2007). Örgütsel davranış açısından kişiliğin önemi. İş, Güç Endüstri İlişkileri Ve İnsan Kaynakları Dergisi, 3 (1), No.96

Aytaç, S., ve Başol, O. (2018). Mediating role of loneliness and organizational conflict between work overload and turnover intention. Proceedings of the 20th Congress of the International Ergonomics Association içinde (s. 291-301), 2018, İtalya.

B.Arthur, M., Hall, D. T. ve Lawrance, B. S. (1989). Handbook of career theory (1 bsm.). New York: Cambridge University Press.

Baron, R. M., ve Kenny, D. A. (1986). The moderator-mediator variable distinction in social psychological research: Conceptual, strategic and statistical considerations. Journal of Personality and Social Psychology, 51 (6), 1173-1182.

Barutçugil, P. D. (2004). Stratejik insan kaynakları yönetimi. İstanbul: Kariyer Yayınları.

Bell, R. A., Roloff, M. E., Camp, K. V. ve Karol, S. H. (1990). Is it lonely at the top?: Career success and personal relationships. Journal Of Communication, 40(1), 9-23.

Bowen, D. E., ve Lawler, E. E. (1992). The empowerment of service workers: What, why, how, and when. Sloan Management Review, 33(3), 31-39.

Büyüköztürk, Ş. (2010). Sosyal bilimler için veri analizi el kitabı. Ankara: Pegem Akademi Yayınları

Cai, C., ve Zhou, Z. (2009). Structural empowerment, job satisfaction and turnover intention of chinese clinical nurses. Nursing And Health Sciences, 11, 397-403.

Can, A. (2017). SPSS İle bilimsel araştırma sürecinde nicel veri analizi (5. b.). Ankara: Pegem Akademi.

Cattel, R. B. (1946). Personality structure and measurement. British Journal Of Psychology, 36 (3), s. 159-174.

Cheng, H., ve Furnham, A. (2002). Personality, Peer Relations And SelfConfidence As Predictors Of Happiness And Loneliness. Journal of Adolescence, 25, 327-339. 
Conger, J. A., ve Kanungo, R. N. (1988). The Empowerment Process:Integrating Theory and Practice. Academy ol Management Review, 13 (3), 471-482.

Costa, P. T., Busch, C. M., Zonderman, A. B., ve R.McCrae, R. (1986). Correlations of MMPI factor scales with measures of the five factor Model Of Personality. Journal Of Personality Assessment, 50 (4), 640650.

Çetin, A., ve Alacalar, A. (2016). İş yaşamında yalnızlığı yordamada kişilik özellikleri ile algılanan sosyal ve örgütsel desteğin Rolü. Uluslararası Yönetim İktisat Ve İşletme Dergisi, 12 (27), 193-216.

Dan, X., Xu, S., Liu, J., Hou, R., Liu, Y., ve Ma, H. (2018). Relationships among structural empowerment, innovative behaviour, self-efficacy and career success in nursing field in Mainland China. International Journal Of Nursing Practice, e12674, s. 1-9.

Doğan, T., Çetin, B., \& Sungur, M. Z. (2009). İş yaşamında yalnızlık ölçeği Türkçe formunun geçerlilik ve güvenilirlik çalışması. Anadolu Psikiyatri Dergisi, 10, 271-277.

Durmuş, B., Yurtkuru, S., ve Çinko, M. (2011). Sosyal bilimlerde Spss'le veri analizi. (4 bsm.). İstanbul: Beta Yayıncilık.

Erdirençelebi, M., ve Ertürk, E. (2018). Çalışanların örgütsel yalnızlık algısının iş tatmini ve işten ayrılma niyeti üzerine etkileri. Gaziantep University Journal Of Social Sciences, 17 (2), 603-618.

Ertosuna, Ö. G., ve Erdil, O. (2012). The effects of loneliness on employees' commitment and intention to leave. Procedia-Social and Behavioral Sciences, 41, $469-476$.

Fatahi-Bayat, G., Goudarzi, A., ve Goudarzi, M. (2016). Study on variables influencing the employee empowerment case study: Industries of Markazi Province. Mediterranean Journal Of Social Sciences, 7 (5), 102-110.

Honold, L. (1997). A review of the literature on employee empowerment. Empowerment In Organizations, 5 (4), 202-212.

John, O. P., Naumann, L. P., ve Soto, C. J. (2008). Paradigm shift to the integrative big-five trait taxonomy: History, measurement, and conceptual issues. (O. P. John, R. W. Robins, ve L. A. Pervin Eds.) Handbook of personality: Theory and research, içinde (s.114-158).New York:Guilford Press. 
Kanter, R. M. (1977). Men and women of the corporation. New York: Basic Books.

Kanter, R. M. (1979). Power failure in management circuits. Harvard Business Review, 57 (4), 65-75.

Kanter, R. M. (1993). Men and women of the corporation (New Edition b.). New York: Basic Books.

Kayri, M. (2009). Araştırmalarda gruplar arası farkın belirlenmesine yönelik çoklu karşılaştırma (Post-Hoc) teknikleri. Fırat Üniversitesi Sosyal Bilimler Dergisi, 19 (1), 51-64.

Laschinger, H. K., Gilbert, S., Smith, L. M., ve Leslie, K. (2010). Towards a comprehensive theory of nurse/patient empowerment: Applying kanter's empowerment theory to patient care. Journal Of Nursing Management 18, 4-13.

Laschinger, K. S., ve Heather, D. (2012, Ocak). Conditions For Work Effectiveness Questionnaire I And II. 2019 tarihinde https://www.uwo.ca/fhs/hkl/cweq.html adresinden alınd1.

Levin, I., ve Stokes, J. P. (1986). An examination Of The Relation Of Individual Difference Variables To Loneliness. Journal Of Personality, 54 (4), 718-733.

McCrae, R. R., ve Costa, P. T. (1997). Personality trait structure as a human universal. American Psychologist, 52 (5), 509-516.

McCrae, R. R., Jang, K. L., Livesley, W. J., Riemann, R., ve Angleitner, A. (2001). Sources of structure: Genetic, environmental and artifactual influences on the covariation of personality traits. Journal of Personality, 69 (4), 511-535.

Menon, S. T. (2001). Employee empowerment: An integrative psychological approach. Applied Psychology: An International Review, 50 (1), 153-180.

O'Brien, J. L. (2010). Structural Empowerment, Psychological Empowerment And Burnout In Registered Staff Nurses Working in Outpatient Dialysis Centers, Master Thesis, The StateUniversity Of New Jersey, New Jersey.

Özçelik, H., ve Barsade, S. (2011). Work loneliness and employee performance. Academy of Management Proceedings, 1, 1-6. 
Perlman, D., ve Peplau, L. A. (1984). Loneliness research: A survey of empirical findings. (I. L. Eds.) Preventing The Harmful Consequences Of Severe And Persistent Loneliness içinde (s. 13-46). U.S. Government Printing Office: DDH Publication No.(ADM).

Ponzetti, J. J. (1990). Loneliness among college students. Family Relations, 39 (3), 336-340.

Rhodes, J. L. (2014). Loneliness: How superficial relationships, identity gaps and social support contribute to feelings of loneliness at Pepperdine University. Pepperdine Journal Of Communication Research 2, 1-15.

Schmitt, D. P., Allik, J., McCrae, R. R., ve Benet-Martínez, V. (2007). The geographic distribution of big five personality traits: Patterns and profiles of human self-description across 56 nations. Journal Of Cross-Cultural Psychology, 38 (2), 173-212.

Sümer, H. C., Bilgiç, R., Sümer, N., ve Erol, T. (2005). Personality attributes as predictors of psychological well-being for NCOs. The Journal of Psychology, 139 (6), 529-544.

Süren, S. (2015). Banka çalışanlarında tükenmişlik ve beş büyük kişilik özellikleri arasındaki ilişki: Bir alan araştırması. Balıkesir: Balıkesir Üniversitesi Yayınları.

Thomas, K. W., ve Velthouse, B. A. (1990). Cognitive elements of empowerment: An "interpretive" model of intrinsic task motivation. Academy Of Management Review, 15 (4), 666-681.

Tolay, E., Sürgevil, O., ve Topoyan, M. (2012). Akademik Çalışma Ortamında Yapısal ve Psikolojik Güçlendirmenin Duygusal Bağlllık ve İş Doyumu Üzerindeki Etkileri. Ege Akademik Bakış, 12 (4), 449465.

Ton, İ. A. (2008). Bireycilik toplulukçuluk ve güvenin işyerinde güçlendirmeye olan etkileri. İstanbul: Beta Basım Yayım Dağıtım.

Weiss, R. S. (1973). Loneliness: The Experience of emotional and social isolation. Cambridge: MA: MIT Press.

Wright, S. L. (2005). Loneliness in the workplace. Master Thesis, Philosophy In Psychology . University of Canterbury, Canterbury.

Wright, S. L., Burt, C. D., ve Strongman, K. T. (2006). Loneliness In The Workplace: Construct Definition And Scale Development. New Zealand Journal Of Psychology, 35 (2), 59-68. 
Yasım, Y. K., ve Işık, U. (2017). Yapısal güçlendirmenin örgütsel vatandaşlık davranışı üzerine etkisi: Taş işleme sektörü. Ordu Üniversitesi Sosyal Bilimler Araştırmaları Dergisi, 7 (2), 377-386.

Zhou, X. (2018). A review of researches workplace loneliness. Psychology 9, 1005-1022.

\section{Kaynakça Bilgisi / Citation Information}

Sever, E. ve Paksoy, M. (2019). Personel güçlendirmenin iş yaşamında yalnızlık üzerindeki etkisinde kişilik özelliklerinin aracılık rolü OPUS-Uluslararası Toplum Araştırmaları Dergisi, 12(18. UİK Özel Sayıs1), 373-409. DOI: 10.26466/opus.584629 